\title{
Mortuary Pottery and Sacred Landscapes in Complex Hunter-gatherers in the Paraná Basin, South America
}

\author{
Daniel Loponte, Flavia Ottalagano, Maricel Pérez, Laura Malec, \\ Cinthia Ramos, Patricia Bozzano, Manuel Iribarren, Rodolfo Pérez, \\ Graciela Leiva, Silvia Domínguez, Sheila Alí \& Alejandro Acosta
}

Tubular pottery comprises certain peculiar artifacts that were produced by late Holocene complex hunter-gatherer societies in southeastern South America for unknown purposes. Some authors have related them to mortuary behaviour which has also been suggested by historical sources, while others have considered domestic use. In this paper, the technical, compositional and functional properties of these artifacts are explored in order to contrast both hypotheses, given an example of how technical analysis allows the identification of special pottery within archeological contexts. This analysis includes a study of the fabrics involved using low and high magnification, thin sections, Scanning Electron Microscopy, Energy Dispersive X-ray Spectroscopy, Mössbauer Spectroscopy, Laser Induced Breakdown Spectroscopy and fatty acid profiles. The results show that these tubular artifacts are not fit structurally for utilitarian purposes and show no evidence of domestic use. Based on these results and on historical data, it can be postulated that they were used as part of mortuary rituals, thus becoming part of the select global group of pottery manufactured exclusively for mortuary purposes.

\section{Introduction}

So-called tubular pottery comprises ceramic artifacts of unknown use recovered from Late Holocene archaeological sites generated by the complex huntergatherers of southeastern South America, especially in the middle and lower basins of the Paraná and Uruguay Rivers up to the Salado River valley (Aldazabal 1995-96; Brunazzo 1999; Caggiano 1984; Díaz 1977; Farías 2005; Freitas 1942; 1953a,b; Frère 2015; Gaspary 1945; 1950; Ghiani Echenique et al. 2013; González 2005; Hilbert 1991; Lafon 1971; Loponte 2008; Lothrop 1932; Márquez Miranda 1932; Oliveira Cézar 1895; Ottalagano 2013; 2015; Ottalagano \& Pérez 2013; Paleo \& Pérez Meroni 2005-06; 2008; Pérez 2017; Schmitz et al. 1972; Serrano 1922; 1931; 1933; 1972; Vignati 1942) (Fig. 1).
These artifacts have a totally unique morphology within what is known in the typology of archaeological ceramics worldwide, and to prove one of the hypotheses raised here would add the tubular artifacts to the select group of ceramics exclusively manufactured for mortuary purposes, of which there are very few examples in the world. The initial hypothesis about their use began with ethnohistorical sources. They indicated a mortuary usage for similar devices, at the same time explaining the meaning of their complex designs and allowing us to look into the symbolic conception of life after death within these ethnographic groups, which we could eventually extend to pre-Columbian times; knowledge that archaeologists can rarely recognize with any degree of certainty. Also, the symbolic meaning of these devices, which involves life after 

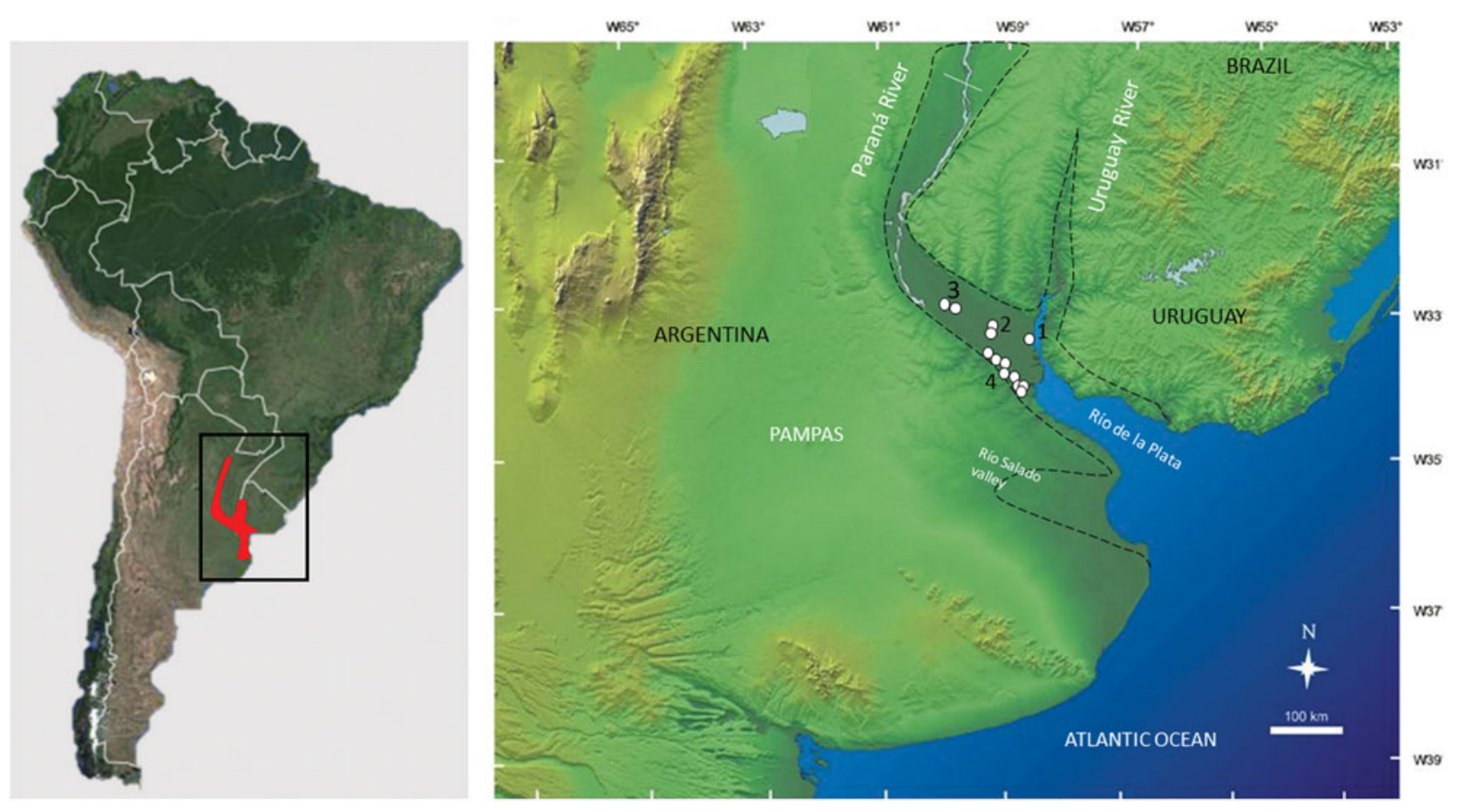

Figure 1. (Left, shaded). The known dispersion range (approximately) of tubular artifacts in South America. (Right) The southernmost distribution range with the locations of the sites where the samples were taken for this study: (1) Cerro Lutz; (2) La Argentina and Isla Lechiguanas site 3; (3) La Fortuna and Las Tejas San Nicolás site 1; (4) La Bellaca (sites 1, 2 and 3), Anahí, Guazunambí, Punta Canal, Rancho Largo, Túmulo de Campana (sites 1 and 2), Médanos de Escobar, El Cazador 3 and El Espinillo.

death in tombs, helps us to increase our understanding about the many ways in which complex huntergatherers went about establishing their ownership of territories by signalling sacred landscapes.

In this study, the tubular artifacts are described and analysed in order to understand their singularity, providing another example of how technical analysis can help to identify symbolic pottery within the archaeological context. This preliminary characterization will allow us to understand better the ethnographic descriptions and interpretation of these artifacts.

\section{The tubular pottery}

These artifacts are associated with different closely related archaeological units, including those informally identified as Plain Pottery Cluster, Incised Pottery Cluster, the so-called Goya-Malabrigo contexts and others that do not yet have a specific cladistic definition (Loponte 2008; Loponte \& Acosta 2016; Serrano 1972). The oldest record to date corresponds to the Playa Mansa site, dated to $2400 \pm 20$ radiocarbon years $\mathrm{BP}$, where what appears to be an apical fragment was recovered (Escudero \& Coll 2013, 28, piece 28.235). The most modern finding corresponds to Cerro Bauer, dated to $242 \pm 24$ radiocarbon years вР (see Table 1), reaching the historical period. Their morphological particularity and spatio-temporal range suggest that these artifacts were a local/ regional development used by human groups who shared a similar lifestyle adapted to continental wetlands and a similar material culture. Tubular artifacts have been recovered from sites interpreted to be residential camps, where burials have also often been detected. These pieces are essentially thick ceramic tubes between 10 and $45 \mathrm{~cm}$ long, open at both ends and conical in shape in most cases (Fig. 2). Their walls are between 6 and $25 \mathrm{~mm}$ thick, with some reaching up to $45 \mathrm{~mm}$ or even more. Those with simpler designs have one narrow end, referred as to apical in this manuscript, and a wider one at the opposite end, referred to as basal. The apical opening measures between 1 and $4 \mathrm{~cm}$ in diameter, while the basal one regularly reaches between 6 and $10 \mathrm{~cm}$. This is the simplest design and it is probable that a significant portion of them have a lateral or medial duct approximately 1 or $2 \mathrm{~cm}$ in diameter 
Table 1. Sites, number of samples and types of analysis carried out for this study. ${ }^{*}$ maximum and minimum radiocarbon dates. ${ }^{* *}$ estimated chronological range (no ${ }^{14} \mathrm{C}$ dates were available). Tub.=tubular; Com.=common vessels.

\begin{tabular}{|c|c|c|c|c|c|c|c|c|c|c|c|c|c|c|c|}
\hline \multirow[b]{2}{*}{ Sites } & \multirow{2}{*}{$\begin{array}{l}\text { Chronology } \\
\text { (radiocarbon years BP) }\end{array}$} & \multirow{2}{*}{$\begin{array}{l}0-100 X \\
\text { Tubular }\end{array}$} & \multirow{2}{*}{$\begin{array}{l}\text { Fresh } \\
\text { breaks Tubular }\end{array}$} & \multirow{2}{*}{$\begin{array}{l}\text { ESEM } \\
\text { Tubular } \\
\end{array}$} & \multirow{2}{*}{$\begin{array}{l}\text { Thin section } \\
\text { Tubular }\end{array}$} & \multicolumn{2}{|c|}{$\begin{array}{l}\text { EDAX } \\
\text { (matrix) }\end{array}$} & \multirow{2}{*}{$\begin{array}{l}\text { EDAX (inclusions) } \\
\text { Tubular }\end{array}$} & \multicolumn{2}{|c|}{ Fatty acids } & \multicolumn{2}{|l|}{ LIBS } & \multicolumn{2}{|c|}{ Mössbauer } & \multirow[b]{2}{*}{ Total } \\
\hline & & & & & & Tub. & Com. & & Tub. & Com. & Tub. & Com. & Tub. & Com. & \\
\hline La Bellaca site 1 & $1110 \pm 70$ & 18 & 2 & 2 & 3 & 2 & 2 & 2 & 1 & & 1 & 1 & 1 & 1 & 36 \\
\hline Cerro Lutz & $1116 \pm 45 / 730 \pm 70^{*}$ & 7 & 3 & 3 & & 1 & 1 & 2 & 1 & 2 & 1 & 1 & 1 & 1 & 24 \\
\hline Punta Canal & $900 \pm 80$ & 2 & 2 & 2 & & 1 & & 1 & 3 & & 1 & 1 & 1 & 1 & 15 \\
\hline Guazunambí & $940 \pm 60$ & 4 & 3 & 3 & 3 & 1 & 1 & 1 & 1 & & 1 & 1 & 1 & 1 & 21 \\
\hline El Espinillo & $1073 \pm 38 / 1046 \pm 35^{*}$ & 10 & 3 & 3 & 3 & 2 & 1 & 1 & & & & & & & 23 \\
\hline Anahí & $1020 \pm 70$ & 2 & 2 & 2 & & 1 & 1 & 1 & 2 & & & & & & 11 \\
\hline Médanos de Escobar & $1752 \pm 33$ & 2 & 1 & 1 & & 1 & 1 & & 1 & & & & & & 7 \\
\hline La Argentina & $979 \pm 44 / 1645 \pm 34$ & 4 & 2 & 2 & 1 & 1 & & & 3 & & 1 & 1 & 1 & 1 & 17 \\
\hline Rancho Largo & $1010 \pm 45$ & 6 & 2 & 2 & & 1 & 1 & 2 & 1 & & & & & & 15 \\
\hline El Cazador 3 & $1091 \pm 46 / 921 \pm 45^{*}$ & 7 & & & & & & & & & & & & & 7 \\
\hline Túmulo de Campana 1 & $1754 \pm 49 / 1341 \pm 29^{*}$ & 1 & & & & & & 1 & & & 1 & 1 & 1 & 1 & 6 \\
\hline Túmulo de Campana 2 & $1640 \pm 70$ & & & & & & & & & 4 & & 1 & & 1 & 6 \\
\hline La Bellaca site 2 & $680 \pm 80$ & & & & & & & 1 & & 3 & & & & & 4 \\
\hline La Bellaca site 3 & $728 \pm 27$ & 11 & & & & & 1 & & & & 1 & 1 & 1 & 1 & 16 \\
\hline Cerro Bauer & $242 \pm 24$ & 1 & & & & & & & & & & & & & \\
\hline Las Tejas San Nicolás 1 & $2000-500^{* *}$ & 3 & & & & & & & & & & & & & \\
\hline La Fortuna & $2000-500^{* *}$ & 1 & & & & & & & & & & & & & \\
\hline Isla Lechiguanas site 3 & $2000-500^{* *}$ & 1 & & & & & & & & & & & & & \\
\hline Total & & 80 & 20 & 20 & 10 & 11 & 9 & 12 & 13 & 9 & 7 & 8 & 7 & 8 & 214 \\
\hline
\end{tabular}



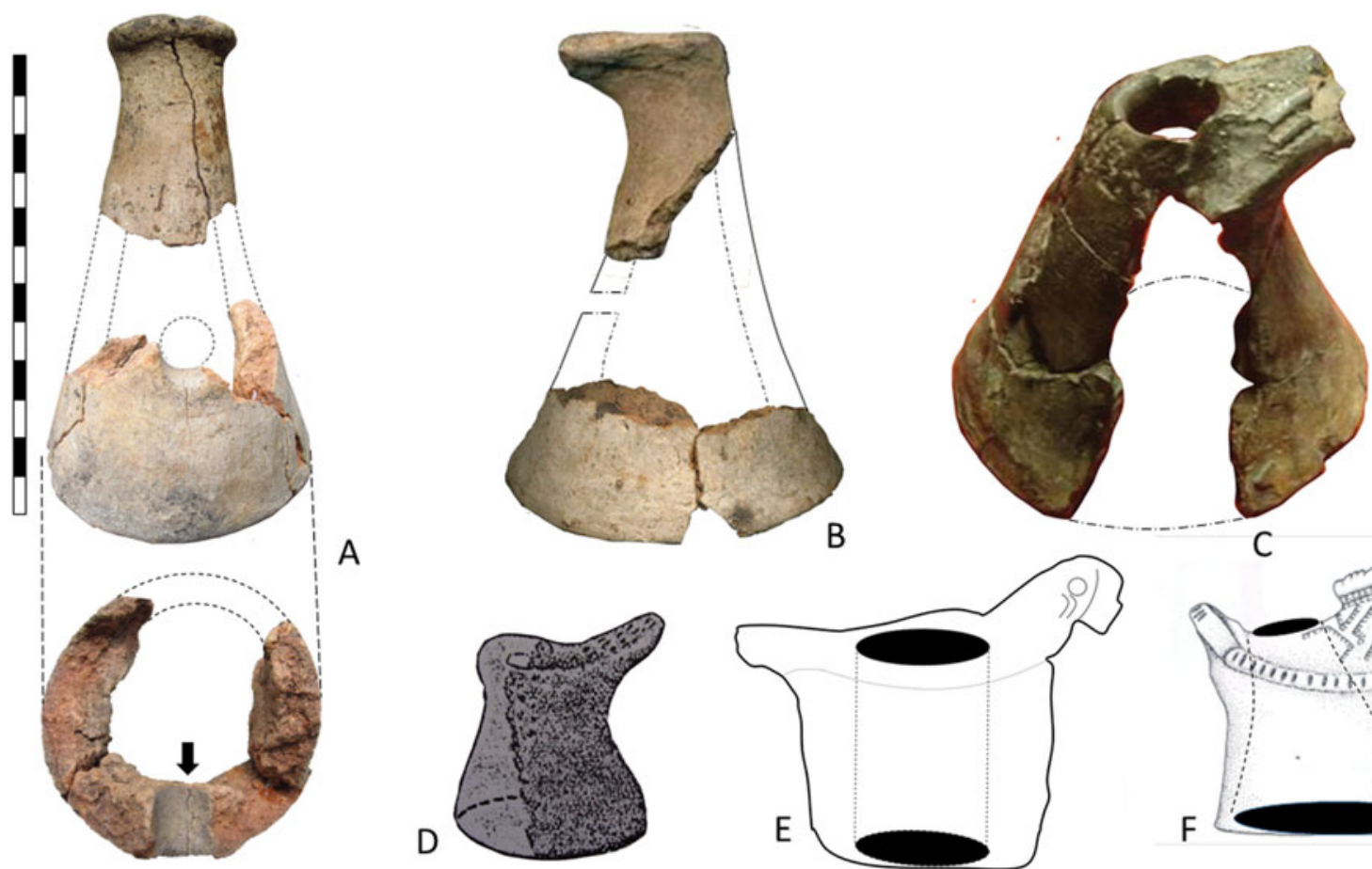

A
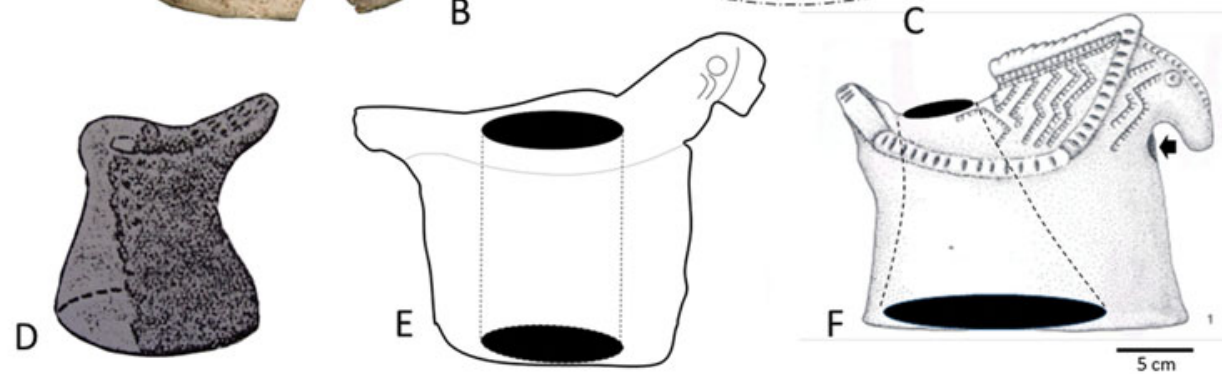

Figure 2. The various tubular pottery designs. (A) Side view of a simple tubular artifact with medial duct (indicated by the dotted circle and arrow). Below, top view of the same basal fragment (La Bellaca site 1); (B) Side view of a simple tubular artifact with solid appendix (La Bellaca site 1); (C) Simple tubular artifact with solid appendage, probably with a zoomorphic design (Talavera Island, private collection); (D) Tubular artifact with extended solid appendage (described as a 'bell' by Gaspary 1950) (Cerro Grande, Isla los Marinos); (E) Lateral view and idealized schematic cut of a tubular artifact with a cylindrical hole with bilateral zoomorphic appendages ('bell'). (Taken and modified from Caggiano 1982.); (F) Lateral view and idealized schematic cut of a tubular device with zoomorphic appendages ('bell'). (Taken and modified from Hilbert 1991.)

on one of their sides (see Fig. 2, piece A; Fig. 4, piece A; see also Loponte 2008, 244). Within this general design, there is a wide variety of forms that have been given different typologies (Caggiano 1984; Díaz 1977; Farías 2005; Gaspary 1945; Hilbert 1991; Serrano 1966; 1972, among others). In some pieces, for example, a solid apical appendage has been added (Fig. 2, pieces B, C \& D). In archaeological units where the pots include zoomorphic appendages, these are often incorporated into tubular artifacts (Fig. 2, pieces C, E \& F) and coexist with the simplest ones. In the most complex tubular pieces, the appendages and modelling acquire an aesthetic predominance over the artifact's basic design, also increasing the size of the base and the apical sector of the central duct (Fig. 2, pieces E \& F, and Fig. 3). In the same way, in assemblages where the pottery is incised, tubular artifacts often have similar incisions (Fig. 4; Loponte 2008, 244). The internal duct, both in simpler and more complex pieces, can be mostly cylindrical or trunk-conical (Serrano 1972).
Tubular artifacts are also called alfarerías gruesas [thick pottery] because of the thickness of their walls, or campanas [bells] because they are approximately campaniform in shape (Caggiano 1984; Gaspary 1945). Some authors only use the descriptive term 'bell' for artifacts with zoomorphic appendages, but these differences are all part of the variation within the general Bauplan. Even Serrano $(1972,48)$ and Gaspary $(1950,40)$, the two authors who began to systematize the study of these artifacts, gave the name 'bells' to tubular artifacts without zoomorphic appendages, but with handles or simple protuberances similar to those observed in some simple tubular artifacts (for example, compare piece B in Figure 2, which is a simpler design, with piece D in the same figure, described as a 'bell' in the literature).

Differences in nomenclature can also be observed in Uruguayan archaeology, where the simplest designs are also called 'botellones' [big bottles] or 'thick pottery' in generic form (Freitas 1953a,b; Hilbert 1991). One of the designs coincides with 


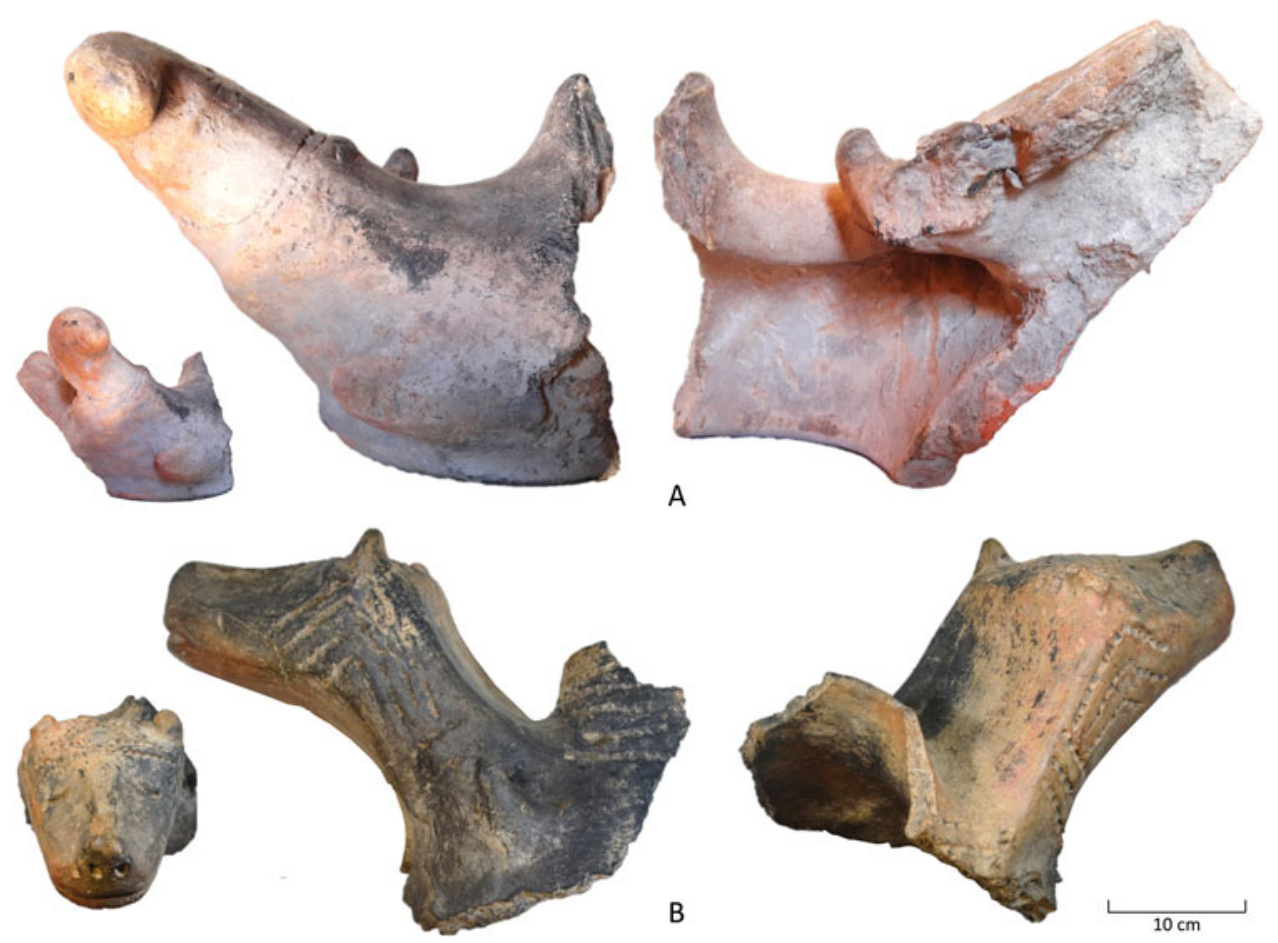

Figure 3. (A) Complex tubular artifact with two front appendages of stylized bird heads (probably the Psittacidae family), curated at La Paz Regional County Museum 'Alicia González Castrillón'; (B) Complex tubular artifact with canid appendage (probably pre-Columbian Canis familiaris), recovered at Las Tejas San Nicolás site 1. In both cases, the inner sides of the central ducts are exposed in the right-hand images.

that of simple tubular pottery open at both ends (Hilbert 1991, fig. 95); but there is another type where the apical end is closed and the medial duct comes very close to this extreme (Hilbert 1991, figs 96 \& 97). Farías (2005), also in the Uruguayan context, distinguishes between alfarería gruesa campanuliforme [campaniform thick pottery] with zoomorphic appendages, and alfarería gruesa cilíndrica [cylindrical thick pottery] or alfarería gruesa tubular [tubular thick pottery], which correspond to the simplest tubular artifacts (see also Díaz 1977). Beneath all this complex descriptive variety, the basic concept is a thickwalled device, wide/open at its lower end and with one or two smaller ducts in its apical and/or medial sectors (Gaspary 1950, 35). The different uses of terminology and structural or morphological characteristics to distinguish between the various designs (i.e. 'thick pottery', 'bells', 'big bottles', 'spouts', 'thick cylindrical pottery', etc.) have created a picture that could lead to some confusion.

Tubular artifacts are often painted white (Farías 2005; Freitas 1953a,b; Frère 2015; Hilbert 1991; Loponte 2008; Ottalagano 2013; Ottalagano et al. in press; Pérez 2017; Vignati 1942; and others). This colour must have had a particular meaning, because utilitarian pots are painted red; meanwhile white paint is extremely rare. This last colour in tubular pottery was applied directly onto the exterior walls after firing (i.e. Fig. 4; Fig. 5B; Fig. 14D), but there are also examples of interior applications (Fig. 5F; Fig. 14C). This occurs in both simple and complex tubular artifacts. The white paint is usually faded and only remains in parts on the surfaces of the sherds, in places where it has resisted erosion, solubilization and entrainment processes which the pigments are subjected to after being buried in the local organic and water-saturated soils. Previous X-Ray Diffraction (XRD) analyses of remnants of this colour on three sherds of complex tubular pieces recovered from sites located on the Middle Paraná River identified hydroxyapatite (Ottalagano et al. in press). A similar result was obtained by Frère (2015), who identified hydroxyapatite in the white pigments used on simple tubular artifacts from the Salado River valley. Following this same concept of white paint, it is common for tubular artifacts to have a cream slip, especially those that are not painted white, with the obvious intention of making their outer appearance whiter (Fig. 2, A \& B; Fig. 14, $B \& C)$. The use of this white slip is again distinctive 

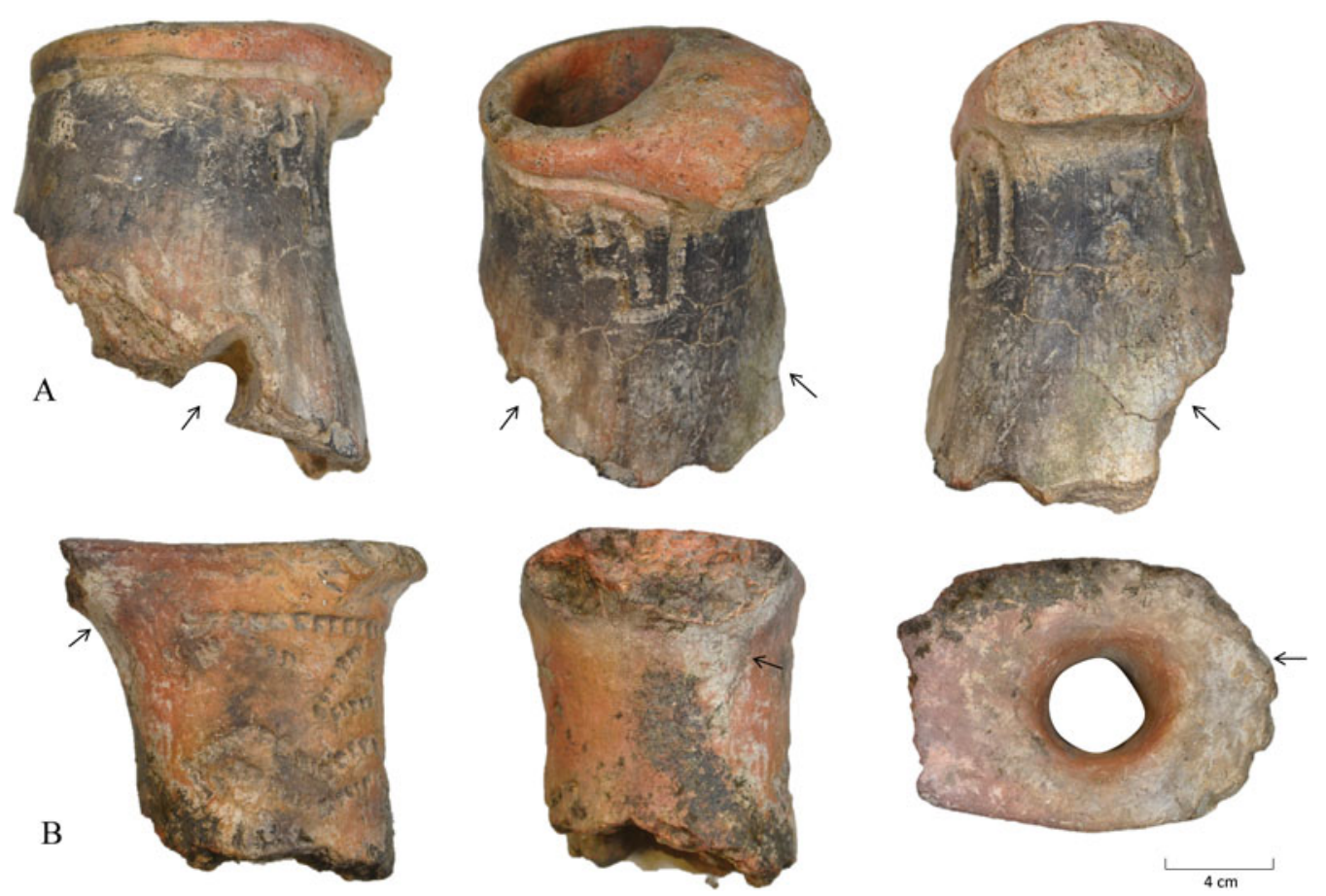

Figure 4. Apical fragments of simple tubular artifacts. Upper row: Side views of piece 101. The medial duct is indicated by a full arrow. Bottom row: Two sides and top view of piece 102. The dotted arrows in both pieces indicate the areas where the white paint is better preserved over the reddish and few black surfaces derived from the firing process. Provenance: Las Tejas San Nicolas site 1 ('Goya-Malabrigo' cluster). The scale is approximate.

of tubular artifacts, as in the collections they came from it was not applied to utilitarian pots, or is extremely rare. These slips are generally better preserved than white pigments, often presenting a cracked appearance. Their application may have involved the addition of a colouring material to the liquid clay, which conceptually can be considered a pre-firing paint (García Rosselló \& Calvo Trías 2013; Ottalagano et al. 2015; Rye 1981). Studies carried out with XRD identified illite as a potential source of the white colour in some complex tubular artifacts. Furthermore, the use of a kind of cast $\left(\mathrm{CaSO}_{4}\right)$, or a related compound, should not be discarded (Ottalagano et al. in press).

In addition to their surface colours, tubular artifacts are made from a very distinctive oxidized fabric, which often results in reddish or orange colors. Conversely, ordinary vessels have a widely predominant dark-coloured matrix in freshly fractured sherds, which indicates the existence of an oxygenreduced firing atmosphere (see below). Another peculiarity of tubular pottery is the absence of carbon deposits and the adhesion of substances or erosion marks (Loponte 2008; Pérez 2017; for the contrary, see Frenguelli 1927 and Aversente et al. ms.). The tendency to lack macro organic residues is particularly striking, given that the internal channels of simple tubular artifacts are narrow and usually poorly smoothed down with a rough surface which is ideal for retaining substances that have circulated through this inner channel.

Finally, it should be noted that while the apical ends in simple pieces usually have an irregular profile, the basal ones are regular and have the same tangential plane around their perimeters, which makes them suitable for eventually being supported on soil or other surfaces. Concurrently, the trunk-conical format helps maintain a vertical axis of stability at rest. In the same way, pieces with large appendages are arranged in opposite directions to maintain their balance, as shown in Figure 2, pieces E and F.

\section{Functional hypotheses}

Torres (1910) and Serrano (1929) considered that the most complex tubular artifacts had a totemic character as an iconic symbol of identity, mainly due to their peculiar structure and zoomorphic appendages. However, it should be noted that ordinary pots from the same context also often have zoomorphic 

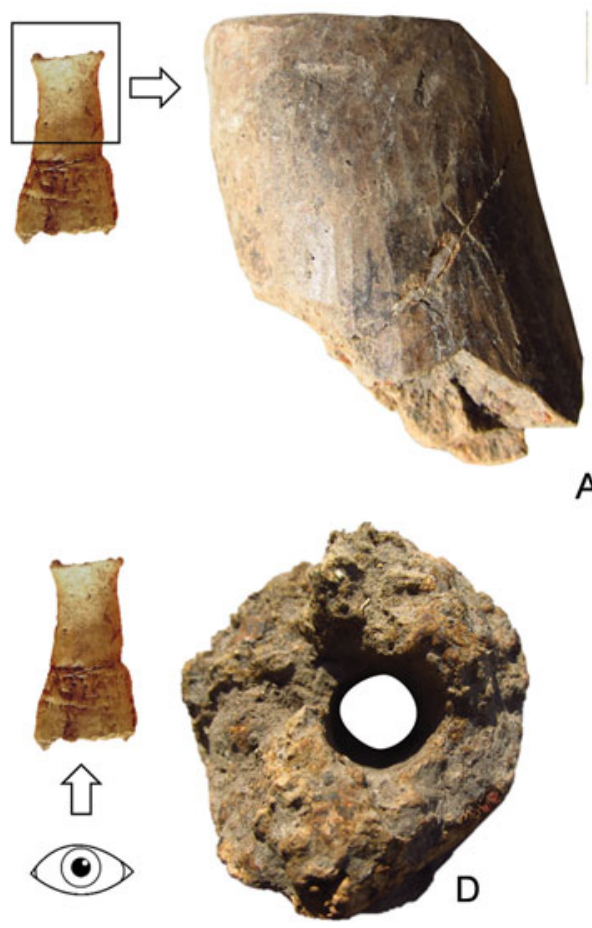

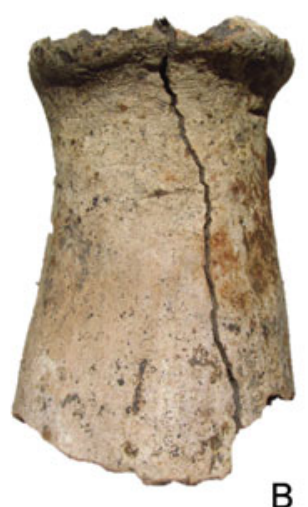

B

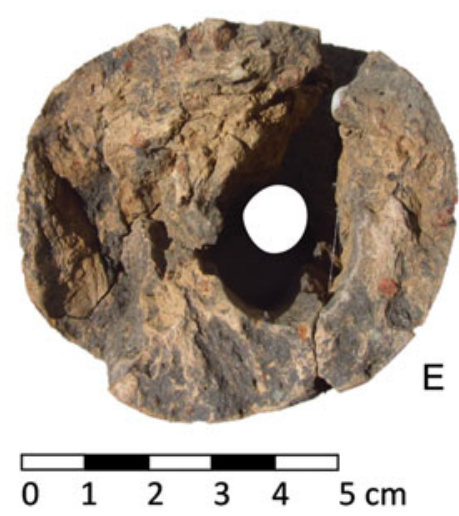

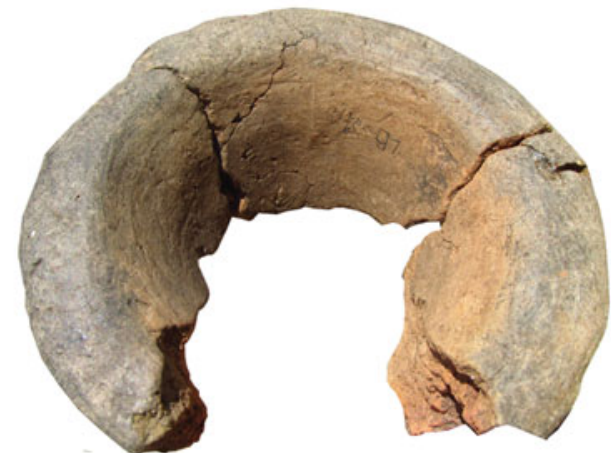

C

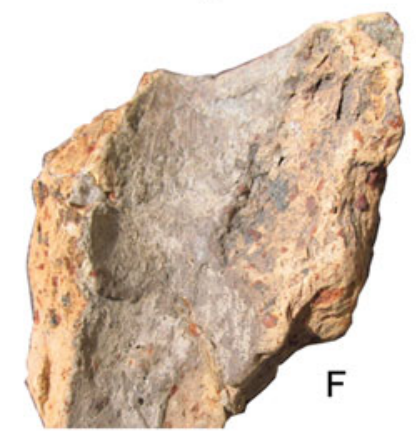

Figure 5. (A) Apical sector with smoothing and burnishing; (B) Apical sector finished by smoothing and small polishing patches, with traces of white paint; (C) Bottom view of the internal area of a base, finished by circular smoothing; $(D, E)$ Bottom view of the apical duct; $(F)$ Internal view of the irregularly smoothed apical duct. Note the white-grey colouration added with a slip and with white paint superimposed.

appendages (Ottalagano 2013; Serrano 1972). Frenguelli (1927) considered that they were used to conserve fire; that is, burning coals would have been placed inside them. A few years later, Lothrop (1932) considered that the simplest tubular artifacts would have been used as fire dogs, that is, as pedestals for placing pots on the fire. While these artifacts have a similar morphology to those of some fire dogs, as illustrated in the archaeological literature (e.g. Aston 1989), they certainly do not meet some of the classical design requirements as being an adequate area for supporting vessels, including a lack of evidence of abrasion and carbon deposits. Following the hypothesis that associated them with fire, Gaspary (1945) suggested that more complex artifacts were used as incense burners in mortuary contexts. A different idea for the simplest artifacts was postulated by Oliveira Cézar (1895), who considered them spouts for skin bags for transferring liquids. This idea was later followed by Serrano $(1972,22)$ who called them tubos troncocónicos [trunkconical tubes]; nowadays, this hypothesis is followed in a similar fashion by some contemporary authors. Although this idea, like every previous one, is a possible explanation, there is no functional or convincing model for which these heavy artifacts, sometimes up to $20 \mathrm{~cm}$ high, with irregular apical sectors, often painted white and also often with a hole in the medial sector, could have served such purposes. Similarly to the first authors, Lafon (1971) found 'thick pottery' associated with burials at an unidentified site in the south of the province of Entre Ríos, which he considered to be part of a mortuary ritual. This author also gave the name 'thick pottery' to simple tubular artifacts, as is recorded in his field notebooks and on the labels packed with some of these pieces recovered by this researcher. Consistent with the findings of Lafon and some previous authors, Hilbert (1991) considered that tubular artifacts, even the simplest ones, were funerary offerings. In our own excavations carried out at different sites in the Paraná and Uruguay River basins, we have not been able to identify any associations between these artifacts and any type of activity or mortuary structure, but this does 
not prevent us from considering the hypotheses raised by Gaspary, Lafon and Hilbert regarding mortuary usage.

\section{Materials and methods}

In order to advance this study of tubular pottery, after soft cleaning, both the surfaces and pastes of 80 sherds and 20 freshly broken selected sherds were observed with an ESEM FEI Quanta 200 microscope (between 10x and 100×). Thin sections were analysed with a petrographic microscope, comparing the results with those obtained from ordinary pots from a previous analysis. After that, the chemical compositions of the pastes and inclusions of both tubular and ordinary pots were determined by Energy Dispersive X-ray analysis in an EDX Genesis Apex 2, expressed as atomic weight (Wt \%) or coverage area (At \%), and subsequently analysed using Laser Ablation Breakdown Spectroscopy (LIBS). For the latter, each sherd was pulverized in an agate mortar and fired at different temperatures $\left(500^{\circ} \mathrm{C}, 600^{\circ} \mathrm{C}, 700^{\circ} \mathrm{C}\right.$ and $\left.800^{\circ} \mathrm{C}\right)$. In this way, from each fragment of pottery, four sub-samples fired at different temperatures were generated. The cooking temperature control was carried out with a thermocouple type K and a NOVUS-Smartmeter. The samples were cooled in the air and, once at room temperature (RT), they were placed in plastic containers previously washed with alcohol. The resulting samples were analysed with an Ocean Optics $2500+$ device, with a lamp energy of $400 \mathrm{~J}$, a laser of $50 \mathrm{~mJ}$, a focal length of $6.2 \mathrm{~cm}$, a delay time of $2.08 \mu$ s and a detection range of between 200 and $730 \mathrm{~nm}$.

From the previous samples, sufficient quantities were separated to perform an analysis by $\mathrm{Fe}^{57}$ Mössbauer Spectroscopy. The firing times during these essays were selected based on the previous literature (Wagner et al. 1998; 1999; 2000) in order to ensure that the reaction equilibrium for the respective temperatures had been reached. The spectra were taken at RT in a conventional constant acceleration spectrometer in transmission geometry with a ${ }^{57} \mathrm{Co} / \mathrm{Rh}$ source. The measurements were recorded at $10 \mathrm{~mm} / \mathrm{s}$ and then fitted using the NORMOS program developed by Brand (1987). The spectra were fitted to Lorentzian line shapes using a minimum number of doublets and sextets.

In parallel to these analyses, another 13 sherds of simple tubular pottery were selected to determine their fatty acid composition. Approximately $2 \mathrm{~g}$ of the interior sides of the sherds were crushed in a mortar after their surfaces had been scraped to remove any lipids of external origin. The lipids were extracted with $10 \mathrm{ml}$ of chloroform/methanol $(2: 1 \mathrm{v} / \mathrm{v})$ by ultrasonication of the ground samples for 20 minutes at RT. The solids were removed by centrifugation ( $3500 \mathrm{rpm}, 15$ minutes), followed by filtration and then the solvent was evaporated under a stream of $\mathrm{N}_{2}$. The fatty acid methyl esters (FAMEs) were prepared according to Indarti et al. (2005) by adding $\mathrm{H}_{2} \mathrm{SO}_{4} 1 \%$ to methanol and heating at $80^{\circ} \mathrm{C}$ for $1 \mathrm{~h}$. After cooling to RT, $5 \mathrm{ml}$ of $\mathrm{NaCl} 5 \%$ was added and the methyl ester derivatives were recovered with chloroform. The solvent was then removed under nitrogen and the FAMEs were dissolved in $500 \mu \mathrm{L}$ hexane for analysis by gas chromatography.

The FAMEs were analysed using a Shimadzu 17A gas chromatograph equipped with a split injector (ratio set at 1:10) and a flame ionization detector (FID) system. The samples were separated using a capillary column $(30 \mathrm{~m} \times 0.25 \mathrm{~mm}$ i.d., 0.25 $\mu \mathrm{m}$-thick film) and coated with BPX-70 stationary phase (70\% cyanopropyl polysilphenylene-siloxane). The injector and detector temperatures were kept at $230^{\circ} \mathrm{C}$. The carrier gas was nitrogen set at a flow rate of $0.8 \mathrm{ml} /$ minute. The initial oven temperature was $140^{\circ} \mathrm{C}$ for 5 minutes, followed by a $140^{\circ} \mathrm{C}$ to $190^{\circ} \mathrm{C}$ increase at a rate of $4^{\circ} \mathrm{C} /$ minute. This was followed by a 13 -minute hold at $190^{\circ} \mathrm{C}$, after which the temperature was increased to $200^{\circ} \mathrm{C}$ at $50^{\circ} \mathrm{C} /$ minute and remaining at $200{ }^{\circ} \mathrm{C}$ for 2 minutes. Three replicates were analysed for each sample and the peaks were identified by comparing them with several external qualitative standards (Supelco, MO, USA). These results were compared with those previously obtained in ordinary vessels recovered from regional sites and the same temporal block (Pérez et al. 2013). A summary of the performed analyses can be seen in Table 1.

In this paper, we refer to the 'matrix' to identify material with a slime particle size which corresponds to clay; 'paste' means the result of a mixture of the matrix and the inclusions (including the natural and artificial tempers); while the term 'fabric' involves the matrix, the inclusions and the firing conditions. We define 'smoothing' as the process of smoothing the walls of pieces, but leaving their surfaces rough to the touch; 'polished' means the process derived from polishing which leaves surfaces smooth to the touch and without a glossy aspect. We reserve the term 'burnished' for surfaces that, in addition to being smooth to the touch, have a glossy surface. 
Mortuary Pottery and Sacred Landscapes in Complex Hunter-gatherers in the Paraná Basin, South America

\section{Results}

\section{Conservation and fracture processes}

The state of conservation of tubular pottery sherds does not differ from ordinary vessels. The fracture planes are irregular and sharp, showing no significant erosion during their burial process and subsequent depositional stasis within the soil matrix. The shapes of the sherds tend to be quadrangular or irregular (Figs 4 \& 5A, B \& F), typically derived from the fragmentation of modelled artifacts. The simpler pieces frequently show a fracture that divides the artifacts into two large sectors, the apical and the basal, as if the main fracture had happened in the middle sector of all the pieces (Figs 2A, 2B; $4 \mathrm{~A}, 4 \mathrm{~B} ; 5 \mathrm{~A}, 5 \mathrm{~B}$ ). Indeed, complete apical and basal sectors are often recovered, but complete medial sectors are extremely rare.

\section{Manufacture process and inclusions}

The pieces were modelled and/or with paste aggregates with the exception, perhaps, of expanded bases, which could have been made by coiling (Fig. 5C). The internal sectors of the expanded bases generally present a more or less regular smoothing, executed by circular movements (Fig. 5C). As the fragments correspond to the apical sectors, the roughness of the internal surfaces is greater. This is a consistent observation given that the potters did not have full access to the small ducts to smooth or polish them (Figs 5D, E \& F). These axial ducts were probably manufactured in two different ways. In the base area, they were formed by modelling or coiling, while in the apical sector, at least in some pieces, they seem to have been executed by introducing a more-or-less cylindrical object into a solid block of fresh paste, thus displacing part of it. This operation, which could have been executed even with a small stick, was not always performed in an equidistant manner from the future axis of the piece and, therefore, the ducts can be displaced from this axial axis (Figs 5D \& E). External smoothing, which is the most common treatment, was carried out longitudinally, from the basal to the apical sector, or vice versa. Some pieces were subsequently polished or burnished, following the same direction (Fig. 5A). The fabrics are reddish in colour, which denotes a completely oxidated firing atmosphere, which will be discussed in more detail below.

The sections show a sparsely cohesive paste, with numerous lines of cleavage. The textures are loose and friable in most of the samples $\left(\mathrm{x}_{80} \geq\right.$ $90 \%$ ), with a low level of cohesion, often with internal exfoliation processes and numerous interstices (Figs 6, 7E \& 7F), with few exceptions where the pastes are partially more cohesive (Fig. 6E). All the thin sections show a low level of fluidity (Figs 7A, B \& C) derived from lightly kneaded pastes. These are dense, with few pore spaces, oscillating around $\sim 5$ per cent. The same results were obtained from thin sections made on complex tubular artifacts with zoomorphic appendages recovered from sites located on the mid-Paraná River (Ottalagano 2015).

The most abundant inclusions are quartz and opaque minerals (Fig. 7, pieces A, B \& C). Compared with ordinary pots (Ottalagano 2015; Pérez 2017), they have smaller quantities of quartz in their sand fractions. The opaque minerals are basically iron oxides (Table 2; Figs 7D, 8A, B \& C). Their dimensions vary from less than $1 \mathrm{~mm}$ to $\sim 10$ $\mathrm{mm}$ in diameter. In very small quantities, there are crushed ceramics of different sizes $(\leq 10 \mathrm{~mm}$; see Fig. 8D), natural lumps of aluminum silicates (up to $1 \mathrm{~mm}$; Figs 7E \& F, 8D), volcanic shreds, bio-clasts and some carbonized and/or preserved tissues (Fig. 7E).

Opaque minerals and quartz are natural inclusions in some local clay banks and are found in both utilitarian vessels and tubular artifacts. In the latter, opaque minerals tend to include larger ones according to the need to maintain thicker walls (cf. Rye 1981). When cooked they harden, acting as natural tempers. Previous X-ray analysis showed their metallic composition (Loponte 2008), as corroborated by EDAX. In effect, nine of these pellets show a high percentage of $\mathrm{Fe}\left(\mathrm{x}_{9}=37.91 \pm 15.89 \mathrm{Wt} \%\right.$ : see Table 2; or $21.04 \pm 11.89$ At \%). Crushed pottery is also present, but in smaller quantities. The tempers observed by SEM and analysed by EDAX have a similar colour and chemical composition as the matrix (Fig. 6, piece D), with a low concentration of Fe. This occurs in both tubular pottery $\left(\mathrm{x}_{11}=0.96 \pm 0.60\right.$ At $\left.\%\right)$ and ordinary pots $\left(x_{9}=1.21 \pm 0.85\right.$ At $\left.\%\right)$. Finally, the lumps of natural silicates have the same composition as the matrix and crushed sherds, but they are smaller and size-selected $(\sim 200 \mu)$; they generally do not include iron micropellets, as eventually crushed pottery does.

Chemical composition of the matrix in tubular pottery and common pots

The chemical composition of the matrix does not show any substantial differences between tubular and common vessels (see Table 3). However, both groups present some smaller differences including a greater range of variation in the former, thus 

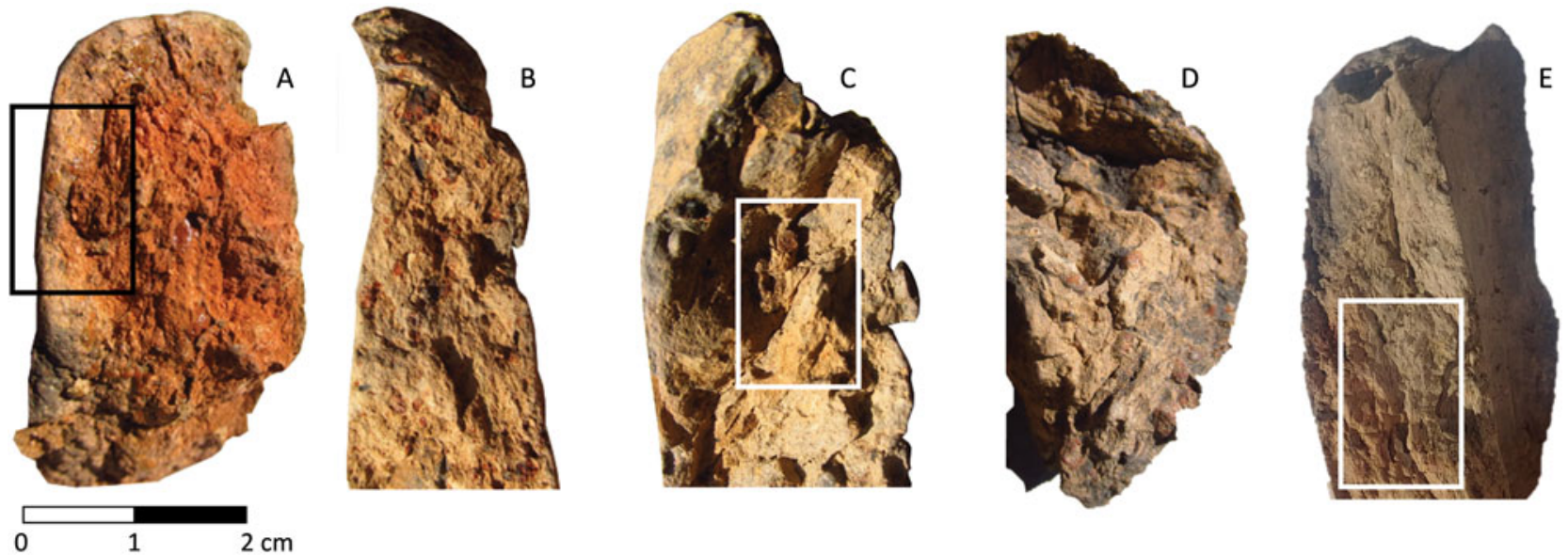

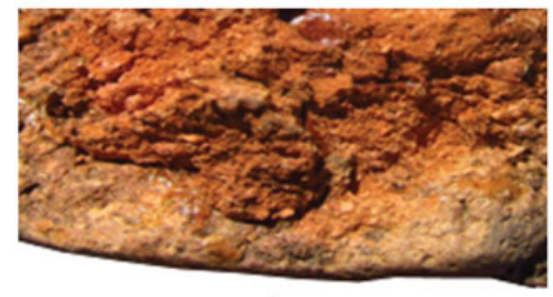

$\mathrm{A}_{1}$

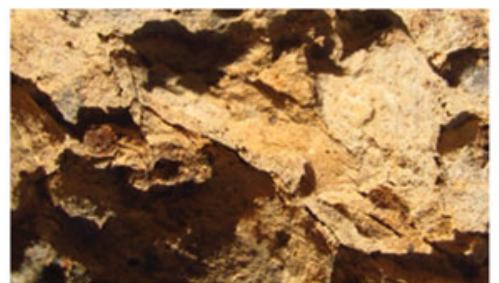

$\mathrm{C}_{1}$

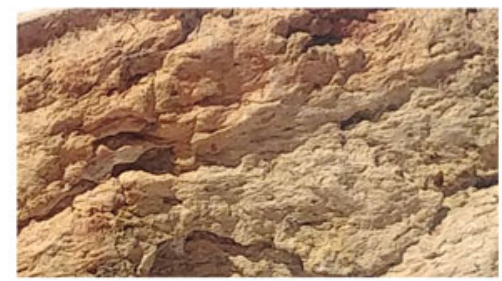

$\mathrm{E}_{1}$

Figure 6. Fresh breaks in tubular artifact walls. Pieces $A-D$ show very friable fabric with cleavage lines (especially pieces $A, C$ and $D)$, and slightly more cohesion in pieces $B$ and $E$.

allowing them to be grouped into different clusters that are, however, not exclusively of each type (Fig. 9).

The LIBS analysis of tubular artifacts and common vessels yielded generally similar results to those obtained with the semi-quantitative EDAX. However, this method has a greater qualitative sensitivity that allowed very small amounts of $\mathrm{Cu}$ and $\mathrm{Ba}$ to be identified in both types and 18 spectral bands (SB) in high proportions found exclusively in tubular pottery (see Figure 10, graphs A \& B). By contrasting these SB values with those provided by the National Institute of Standards and Technology (NIST, USA), manganese emerges as being the only compatible element (Figure 10, graph $C$ by way of example compares samples of both pottery types against the standard).

The intensity of the Mn peaks decreases as a function of temperature; this does not happen with other elements such as K (see Figure 11). The subsample of tubular pottery annealed at $500^{\circ} \mathrm{C}$ had the highest concentration of $\mathrm{Mn}$, which gradually reduced to the lowest concentration in the sub-samples annealed at $700^{\circ} \mathrm{C}$ and remained almost constant at $800^{\circ} \mathrm{C}$, which is the maximum annealing temperature of these samples in the laboratory.
Since Mn compounds are not recognized at these levels in ordinary vessels, it should be ruled out that they are a product of post-depositional contamination and thus differentially added to tubular pottery. Moreover, tubular pottery was fired by aboriginal groups at $800-850^{\circ} \mathrm{C}$ (see below); thus, the only possible explanation for these $\mathrm{Mn}$ spectral bands is a post-firing application of a volatile $\mathrm{Mn}$ compound.

\section{Firing temperatures}

The first remarkable difference between these sets of samples is the colour of the powders resulting from grinding. The former are reddish to light brown due to the action of sufficient temperature and oxygen; meanwhile, the latter are black or dark brown due to reduction conditions (Fig. 12) (Murad \& Wagner 1998; Rye 1981; Wagner et al. 2000).

There are different scenarios for performing a Mössbauer study of archaeological pieces. When clay from an archaeological site is available, the firing context can be emulated in the laboratory under different conditions. A comparison of the Mössbauer spectra corresponding to these controlled experiments can be compared with the spectra of ancient ceramics to identify the original production 

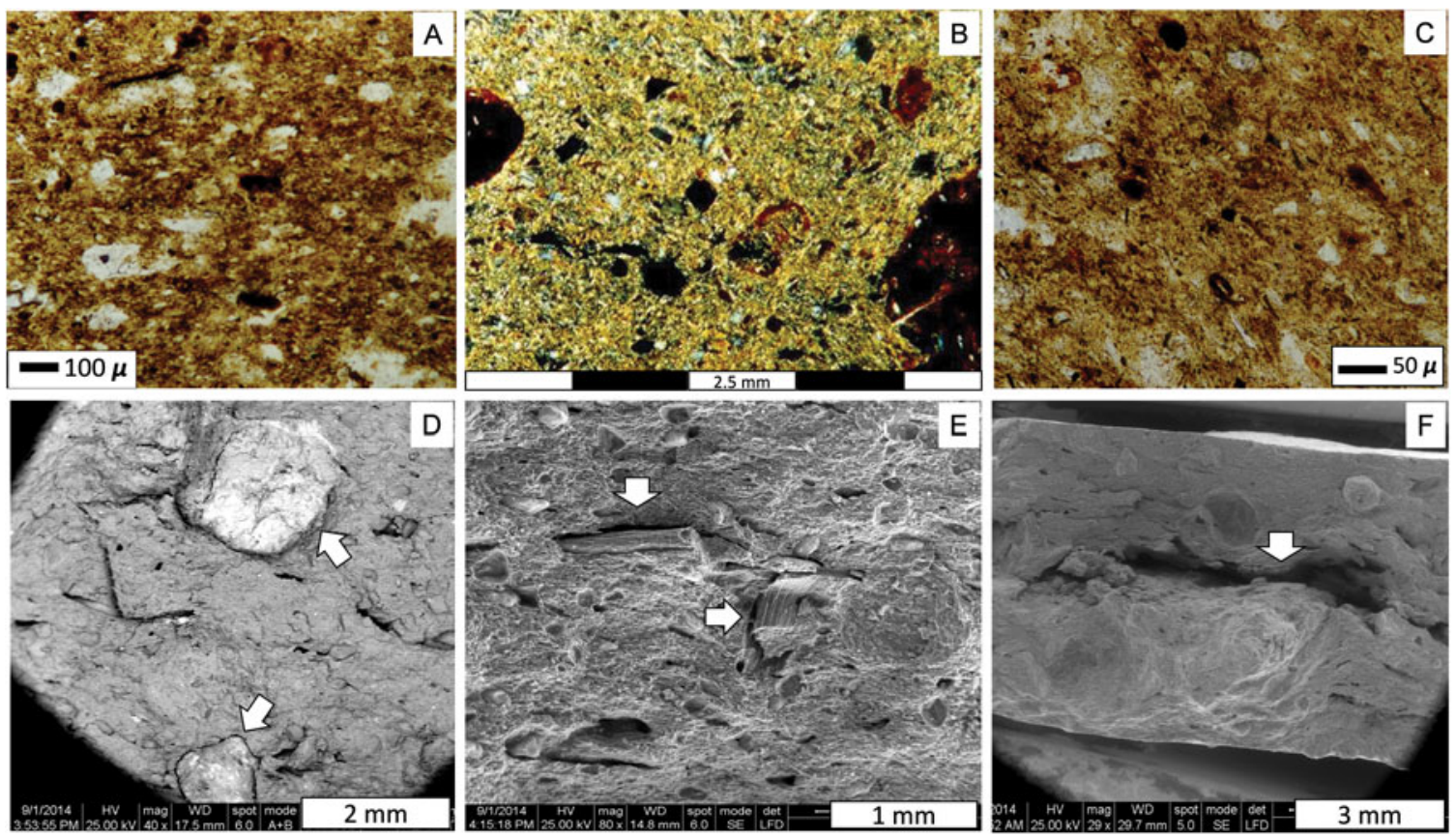

Figure 7. Top row: Thin-section micrographs of a simple tubular pottery captured by a metallographic microscope. The black and reddish inclusions are basically iron oxide slumps of different granulometry. Bottom row: Fresh break micrographs captured by SEM. (D) Iron oxide pellets (bright when observed by ESEM), indicated by the arrows; (E) Preserved tissues, indicated by the arrows, surrounded by natural lumps of aluminum silicate; (F) Empty spaces in the paste.

techniques. If the original clay is not available, refiring the ancient pottery samples in the laboratory may help to determine the original firing conditions. The latter procedure was the one employed to perform the Mössbauer analysis.

The RT Mössbauer parameters that change most sensitively during the oxidizing firing of pottery clays are the quadrupole splitting of the trivalent iron, $\mathrm{QS}\left(\mathrm{Fe}^{3+}\right)$, and the nonmagnetic Anm fraction. When heated in air, there is a strong increase from the QS $\left(\mathrm{Fe}^{3+}\right)$ for fresh clay up to that corresponding to a firing temperature of $400^{\circ} \mathrm{C}$ and reaches a maximum on firing at $700^{\circ} \mathrm{C}$. Then, between $700^{\circ} \mathrm{C}$ and $900^{\circ} \mathrm{C}$, hematite forms from the iron set free from

Table 2. Chemical composition in terms of the atomic composition of black/reddish pellets included in the matrix (Wt \%).

\begin{tabular}{|c|c|c|c|c|c|c|c|c|c|c|c|c|}
\hline Elements & $\mathrm{Fe}$ & O & $\mathrm{Na}$ & $\mathrm{Mg}$ & Al & $\mathrm{Si}$ & $\mathrm{S}$ & K & $\mathbf{P}$ & $\mathrm{Ca}$ & $\mathrm{C}$ & Total \\
\hline Pellet 1 & 16.88 & 43.98 & 0.55 & 0.74 & 8.71 & 23.8 & 0.47 & 3.98 & 0.0 & 0.89 & 0.0 & 100 \\
\hline Pellet 2 & 51.61 & 33.34 & 1.21 & 0.0 & 3.29 & 7.56 & 0.21 & 0.35 & 0.7 & 1.02 & 0.0 & 99.29 \\
\hline Pellet 3 & 29.06 & 29.28 & 9.89 & 0.0 & 0.0 & 25.41 & 0.0 & 5.45 & 0.0 & 0.91 & 0.0 & 100 \\
\hline Pellet 4 & 46.02 & 24.4 & 0.0 & 0.0 & 7.03 & 18.44 & 0.0 & 3.1 & 0.0 & 1.01 & 0.0 & 100 \\
\hline Pellet 5 & 35.18 & 30.35 & 0.0 & 0.0 & 7.7 & 19.52 & 0.0 & 5.95 & 0.0 & 1.3 & 0.0 & 100 \\
\hline Pellet 6 & 51.71 & 28.43 & 1.1 & 0.0 & 3.12 & 9.39 & 0.1 & 0.24 & 0.6 & 0.76 & 4.61 & 100 \\
\hline Pellet 7 & 22.34 & 33.86 & 0.0 & 0.0 & 7.32 & 29.26 & 0.0 & 2.17 & 1.6 & 2.52 & 0.0 & 99.06 \\
\hline Pellet 8 & 63.25 & 13.53 & 0.0 & 0.0 & 4.14 & 9.15 & 0.0 & 1.09 & 3.8 & 4.15 & 0.0 & 99.12 \\
\hline Pellet 9 & 25.14 & 49.04 & 0.23 & 0.0 & 2.11 & 18.01 & 0.18 & 4.19 & 0.0 & 0.80 & 0.00 & 99.7 \\
\hline$x$ & 37.91 & 31.80 & 1.44 & 0.08 & 4.82 & 17.84 & 0.11 & 2.95 & 0.74 & 1.48 & 0.51 & \\
\hline SD & 15.89 & 10.37 & 3.20 & 0.25 & 2.98 & 7.74 & 0.16 & 2.12 & 1.27 & 1.14 & 1.54 & \\
\hline $\mathrm{CV}$ & 41.91 & 32.61 & 222.15 & 300.0 & 61.68 & 43.38 & 151.74 & 72.03 & 172.01 & 76.55 & 300.0 & \\
\hline
\end{tabular}



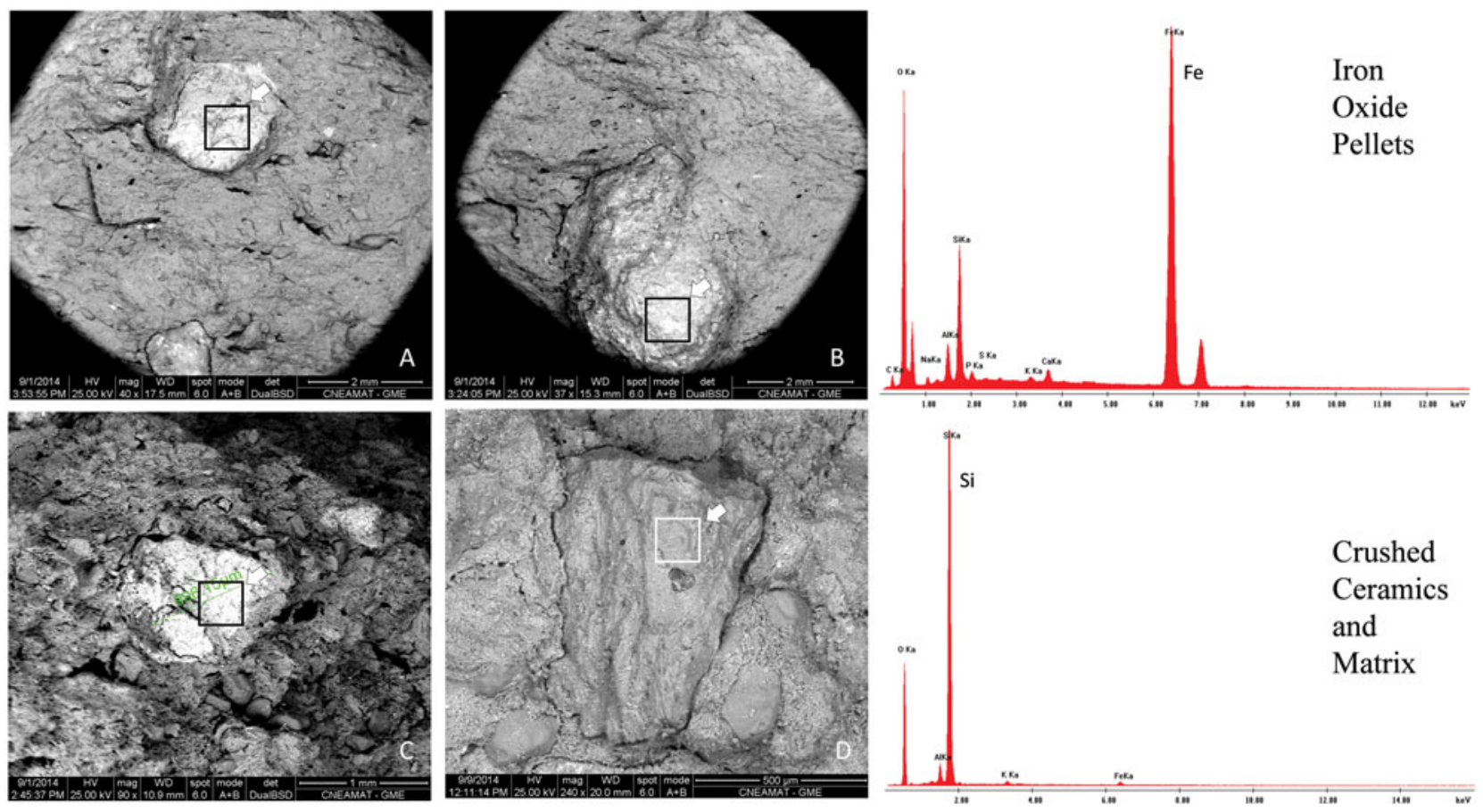

Figure 8. $(A, B, C)$ Iron oxide pellets, which in the above SEM images are bright due to their metallic composition; (D) Crushed ceramic as a temper surrounded by natural lumps of aluminum silicates. The square in each micrograph indicates the area analyzed by EDAX. Top right graphic: Chemical composition of one iron pellet sample. Bottom right graphic: Chemical composition of the crushed pottery in image D.

the clay matrix (Wagner et al. 1999). In a Mössbauer spectrum, the absence of or decrease in $\mathrm{Fe}^{2+}$ is indicative of an oxygen-rich atmosphere in the original firing. For clays fired under reducing conditions, instead a reduction of $\mathrm{Fe}^{3+}$ occurs at around $500^{\circ} \mathrm{C}$ and the $\mathrm{Fe}^{2+}$ content increases until $800^{\circ} \mathrm{C}$, but there is no increase in QS $\left(\mathrm{Fe}^{3+}\right)$ (Murad \& Wagner 1998). In both subsets (tubular and ordinary vessels), the higher percentage of non-magnetic $\mathrm{Fe}^{3+}$ reveals that the sherds were not fired at above $900^{\circ} \mathrm{C}$, when entire structural iron forms hematite. The spectra obtained from samples from ordinary vessels denote firing under reducing conditions at $800^{\circ} \mathrm{C}$, followed by intentional or accidental exposure to oxidation in the air, at around $700-750^{\circ} \mathrm{C}$, after the firing cycle. The result of these firing conditions consists of sherds with black cores and slightly lighter external surfaces or with a thin reddish layer. The spectra obtained from tubular samples, in turn, indicate firing at $800^{\circ} \mathrm{C}$ under a reducing atmosphere, followed by oxidation at the end of the firing cycle, which started at higher temperatures, around $800-850^{\circ} \mathrm{C}$. In the Mössbauer spectra, this is seen as a decrease in non-magnetic areas (doublets) due to the formation of hematite (sextet), because at elevated temperatures (above $700^{\circ} \mathrm{C}$ ) small hematite particles may coalesce into larger ones (Wagner et al. 2000). As an example, in Figure 13, the Mössbauer spectra for sample 5 (ordinary vessel) and sample 9 (tubular) refired at $500^{\circ} \mathrm{C}, 600^{\circ} \mathrm{C}, 700^{\circ} \mathrm{C}$ and $800^{\circ} \mathrm{C}$ are shown.

\section{Carbon deposits and evidence of use}

An inspection of 80 fragments, many corresponding to large fragments of tubular artifacts, did not allow any evidence of carbon or organic residues to be identified, with the exception of a single fragment (Fig. 14B), which showed an encrusted residue on the inner side. This adherence has not yet been analysed, but it could correspond to a post-depositional process as well as an archaeological event. A similar encrustation was found on the inner side of a complex tubular artifact with a large zoomorphic appendage of a canid (Fig. 3). The lack of carbon and other residues is not due to erosion or other postdepositional processes, since common vessels at the same sites regularly present evidence of carbon on their external walls. Contrarily, the incrustations observed on tubular pottery correspond to the sediments at the sites, oxides and/or carbonates, resulting from natural processes that occur in the regional mollisols. The absence of traces of carbon 


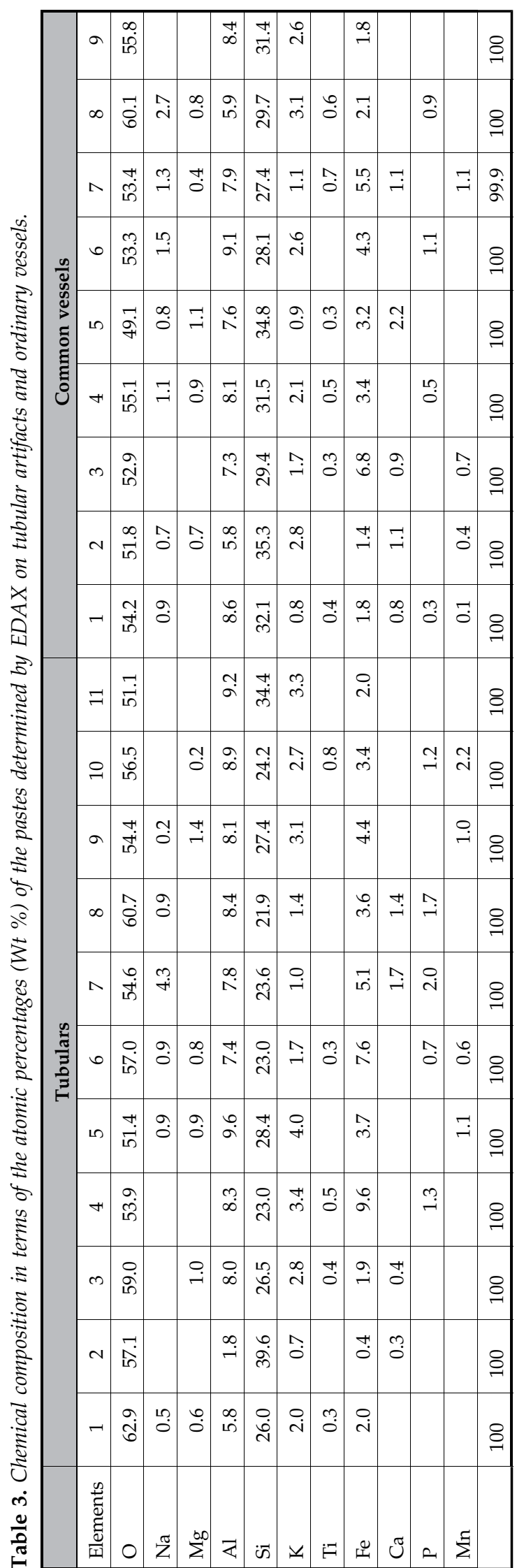

is remarkable, including the sectors of the internal ducts that have white paint, where it would be noticed quickly, as well as in sectors that are rough enough to be able to retain the carbonaceous microparticulate products of combustion. This inspection also made it possible to rule out the existence of scratch marks or some types of friction both on the internal and external sides of the walls.

\section{Fatty acids}

The analysis of fatty acids in pottery is recognized as a useful method for analysing the composition of foods held in containers and to understand the technological, morphological, functional and even stylistic variability of ceramics (Barnard \& Eerkens 2007; Condamin et al. 1976; Craig et al. 2011; Eerkens 2002; 2005; 2007; Evershed et al. 1990; 1997; Malainey 2007; Malainey et al. 1999; Skibo 2013; Skibo \& Deal 1995). The porous microstructure of aluminum silicate, which constitutes the pastes' clay matrix, favours the absorption and retention of the organic matter contained in fatty acids. Most lipids, which are very abundant in foods, are relatively stable over time (Christie 1989; Evershed 1993). The initial burning of vessels eliminates any pre-existing organic matter (Johnson et al. 1988), so vessels began usage without fatty acids in the pastes. In addition, experimental studies have shown that fragments buried in archaeological sediments are not contaminated by fatty acids from the sedimentary matrix (Deal \& Silk 1988; Heron et al. 1991), or they become so very slowly and in low quantities (Charters et al. 1993; Rottländer 1990). For all this, it is considered that the recovered fatty acids in archaeological pottery correspond to its use (Eerkens 2007), unlike the botanical micro-rests recovered from ceramic surfaces, which may simply be a secondary association.

We analysed nine sherds from ordinary vessels taken at random from four archaeological sites in the region. It is estimated that they were mainly used to boil and serve food (Pérez et al. 2013). As a control, four sediment samples were analysed from the four different archaeological sites included in this study, where no fatty acids were detected. Subsequently, 13 fragments of simple tubular pottery recovered from eight sites in the area, which came from the same type of substrate, were analysed. Half of the fragments belonged to the apical and middle sectors of the ducts, and the rest were basal fragments. All of the sherds from ordinary pots presented a wide variety of fatty acids (Table 4), which were related to processing fish, terrestrial mammals and plants 

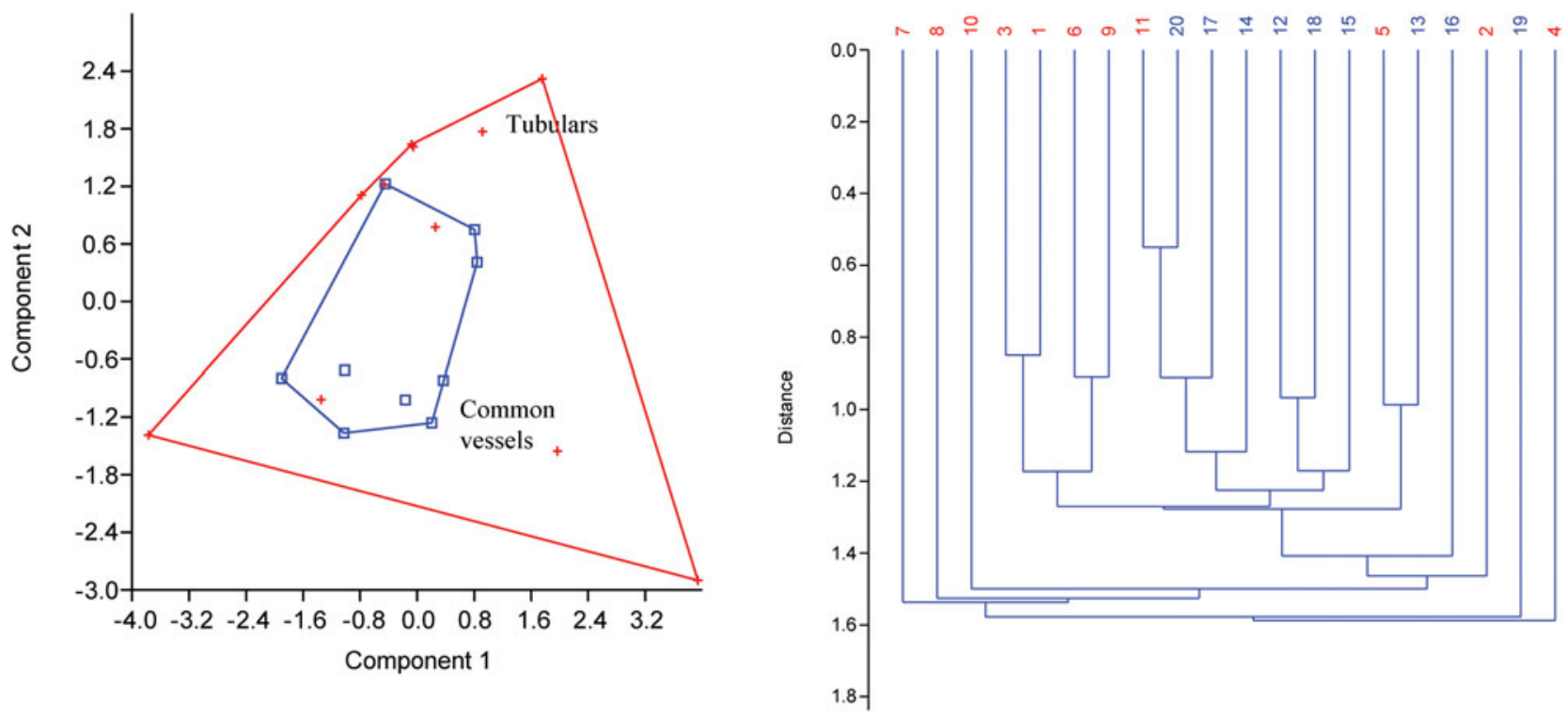

Figure 9. Analysis of the main components (left) and groups of components (Mahalanobis cluster) where the tubular pottery subsets range from samples 1 to 11 (in red +), and the ordinary vessels from samples 12 to 20 (in blue $\square$ ).

(Pérez 2017; Pérez et al. 2013). Following the same detection methodology, no fatty acids were detected in any of the sherds of tubular pottery analysed (listed in Table 1).

\section{Discussion}

The typological and structural peculiarity of tubular artifacts was noticed at an early stage by all of the researchers working in the region. During the segmentation that took place in the literature in the first half of the twentieth century, the simplest were called 'spouts', 'peaks', 'fire dogs', 'tubular pottery', etc., and the more complex were colloquially called 'thick pottery' or 'bells'; this was the beginning of a dissociation that hindered their interpretation, as the former were assumed to have a utilitarian function due to their simpler design, and the latter a symbolic character. However, it is quite clear that both types of artifacts were designed following the same general outline. In contexts where ordinary pottery has zoomorphic appendages, they were usually
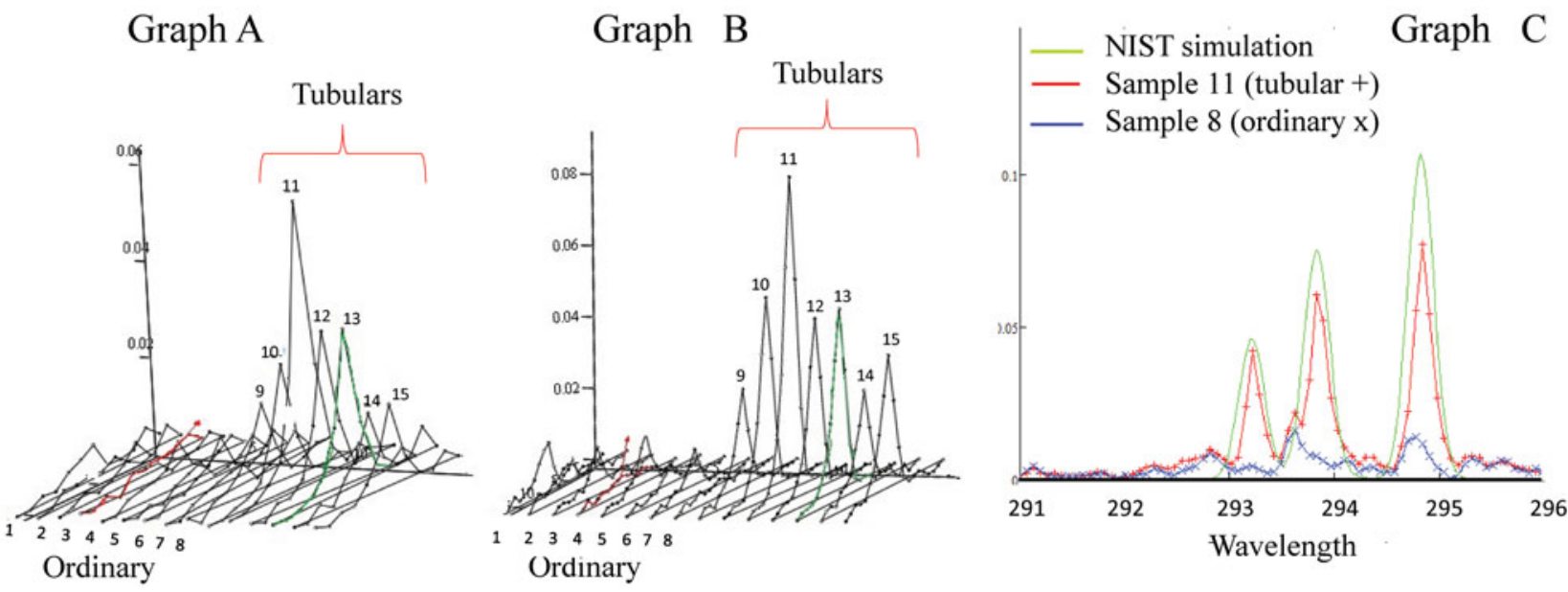

Figure 10. (Graph A) Peaks of $M n \lambda=348.2 \mathrm{~nm}$; (Graph B) Peaks of $M n \lambda=482.1 \mathrm{~nm}$ in tubular pottery samples (pieces 9 to 15) compared to the values of ordinary vessel samples (pieces 1 to 8); (Graph C) NIST simulation (solid green line), which correlates with the triple peak of Mn observed in the tubular pottery in sample 11 (red +line) and shows a lack of correlation with the ordinary vessels in sample 8 (blue $x$ line). 
incorporated into tubular artifacts. As the number of published pieces increases, more examples of intermediate designs between simple and complex forms are recognized. In this sense, the different types can be considered isocrestic variations of the same idea (see Sackett 1985). This Bauplan with spatial drifts and a cultural selection of the different designs includes cumulative changes that evolved over time and space.

When comparing tubular and common pottery, technological and functional differences arise. In the former, the fabrics are of poor quality; they are dense, with few pores, barely kneaded, friable and in general tend to shed and/or exfoliate. There are some pieces with a greater degree of compaction, but in general they are exceptions. These properties do not support a utilitarian use, particularly when compared with ordinary vessels. Tubular artifacts have fewer inclusions of quartz and a slightly different chemical composition in the paste that suggests a different preparation, and they definitely had a differential firing process, resulting in a distinctive fabric. Moreover, they were subjected to a unique treatment to whiten their appearance with the addition of white-grey slips and/or white paint. The eventual addition of a manganese compound would add even more differences to the preparation and/or final use of these artifacts.

From a functional point of view, the differences are also remarkable. In the tubular artifacts studied here, there are no erosion marks or adhered substances (with some exceptions that should be studied properly), fatty acids or carbon residues. Parallel to these results, the overall design and structure of these pieces emphasizes a singular functionality, where a distinctive and peculiar visual impact is offered. The use of calcined bone to obtain the white colour could have been just a technical resource, but it could also have had a symbolic meaning. Together with all the obtained data, the hypothesis that they are artifacts for symbolic use emerges as the best positioned one. The association with burials as indicated by Lafon (1971) seems to be, for the moment, the only finding that would allow them to be linked to any particular activity.

Although we are not certain of the association between these artifacts and the mortuary structures in local archaeological studies, there are ethnographic descriptions that link them explicitly. These historical records were generated from observations of aboriginal groups from the Guaycurú linguistic family, which were located in the same basin towards the north, adjacent to the study area. These groups, in addition to spatial proximity,

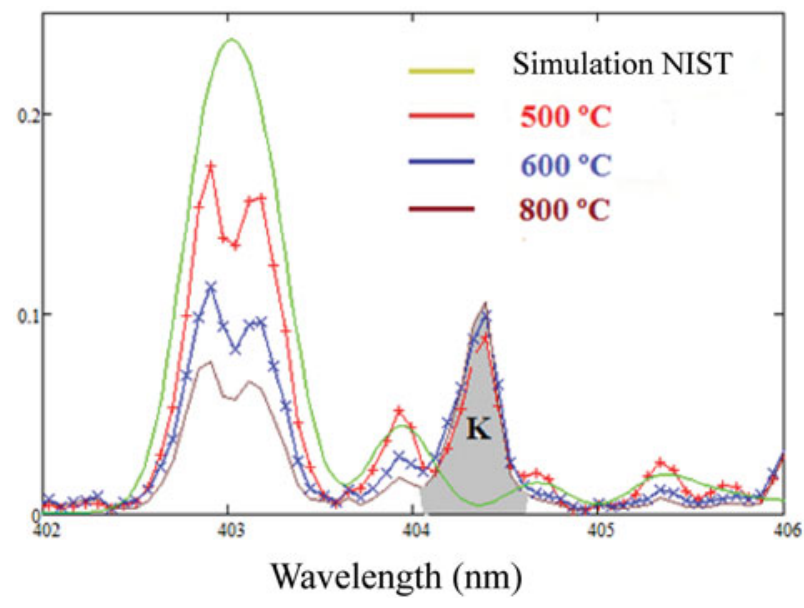

Figure 11. Decreasing $M n$ concentrations according to increasing cooking temperature.

had a lifestyle, material culture and symbolic behaviours similar to those observed in previous populations where tubular artifacts are recorded (Caggiano 1984; Lothrop 1932; Métraux 1937; 1944; 1946; Ottalagano 2013; Palavecino 1933; 1939; Torres 1911). We here transcribe two descriptions that are related to similar artifacts. The first was written

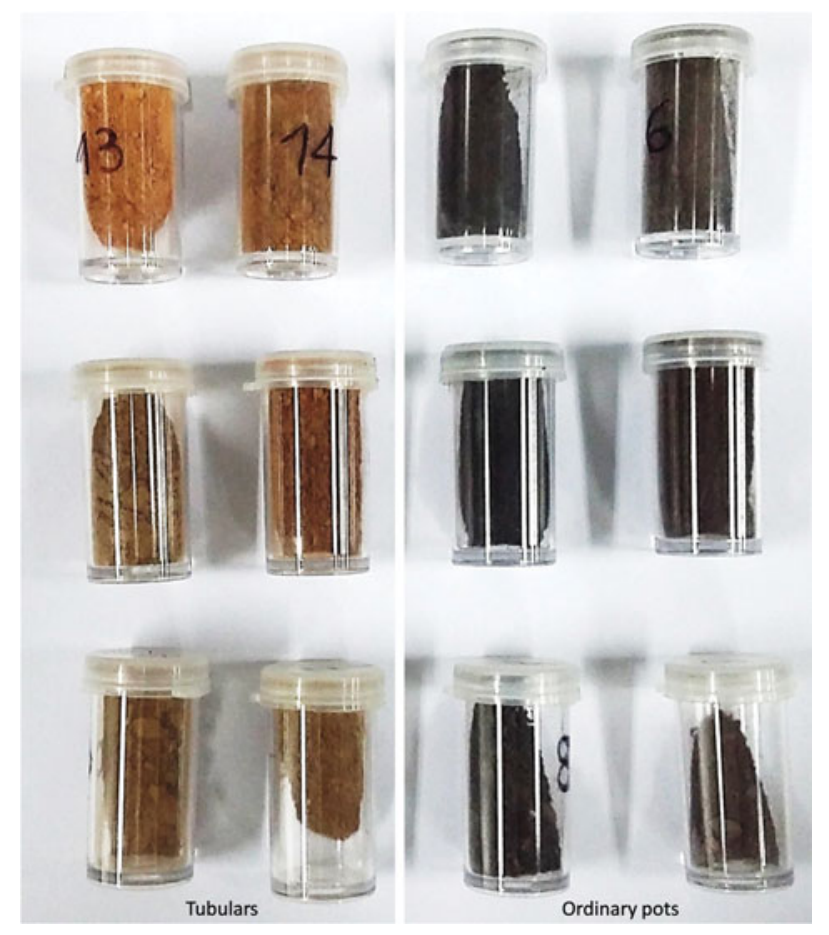

Figure 12. On the left, two columns with six samples of pulverized tubular pottery fragments; on the right, two columns of ground fragments of ordinary vessels. 

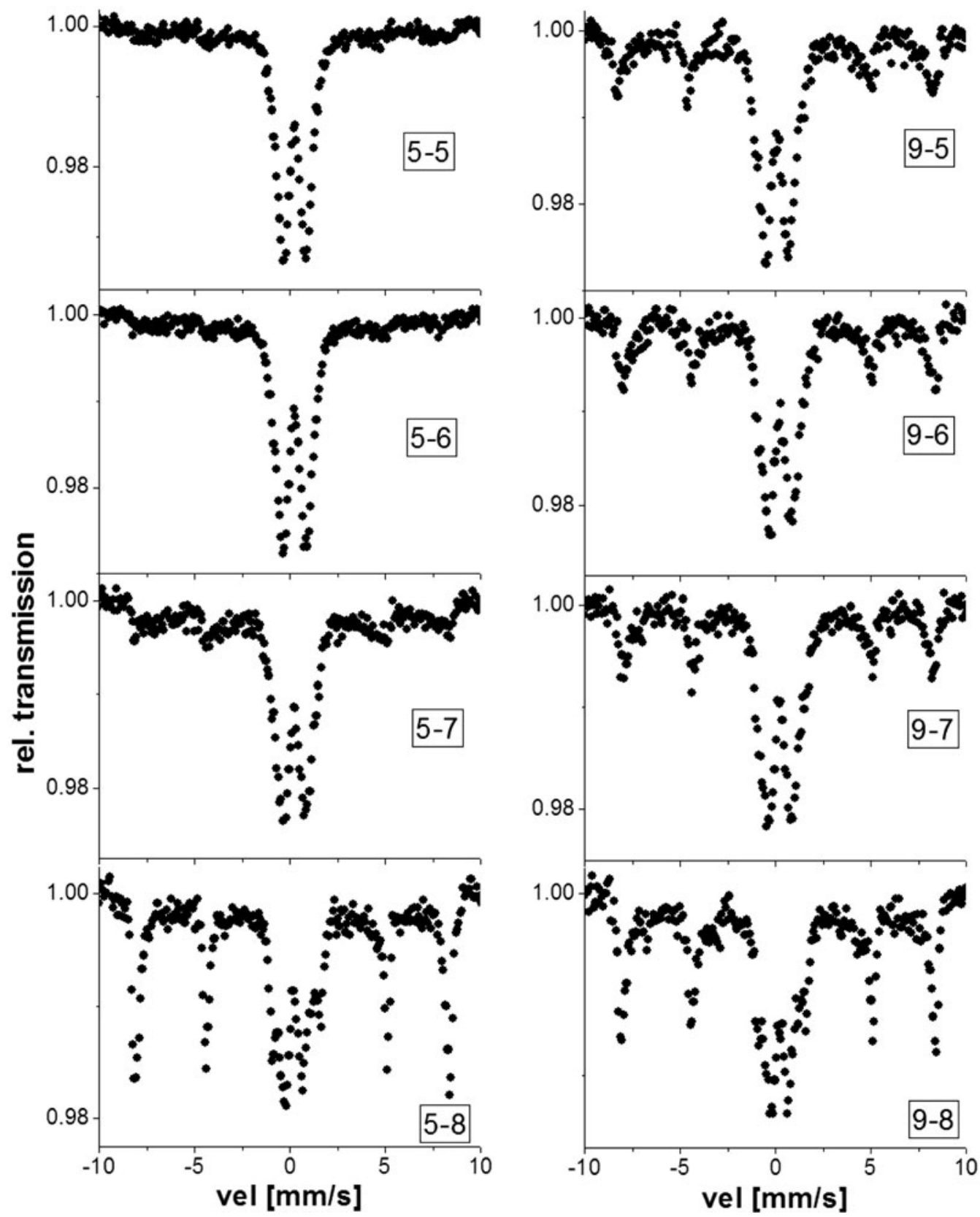

Figure 13. The Mössbauer spectra of samples 5 (left) and 9 (right) refired at $500^{\circ} \mathrm{C}, 600^{\circ} \mathrm{C}, 700^{\circ} \mathrm{C}$ and $800^{\circ} \mathrm{C}$.

by the Jesuit Sánchez Labrador in the eighteenth century:

Sobre cada sepultura había una estera de enea... ponen sobre la estera unos cántaros de varias figuras y grandeza. Unos parecen campanas... y en lugar de asas, en unos hay como una hacha y en otros como una mano de almirez. Los más tenían unos dibujos negros sobre campo blanco... Lo que no se puede penetrar es por qué debajo de los cántaros grandes había dos ó tres chicos de la misma forma; también por qué unos tenían suelo y otros no; $y$, finalmente por qué en todas las sepulturas estaba un cántaro de éstos con tres agujeros, uno a un lado, otro en medio y otro en el fondo. Ofrecióse que dichos agujeros servian para que el espíritu metido en su tinaja, tenga sol, viento y comodidad para registrar lo que pasa por afuera y por dentro de las sepultura, cuando gustare vivir en retiro.

[On each grave there was a mat ... they put some pitchers of various shapes and sizes onto the mat. Some looked like bells... and instead of handles, in some there was something like an axe and in others something 


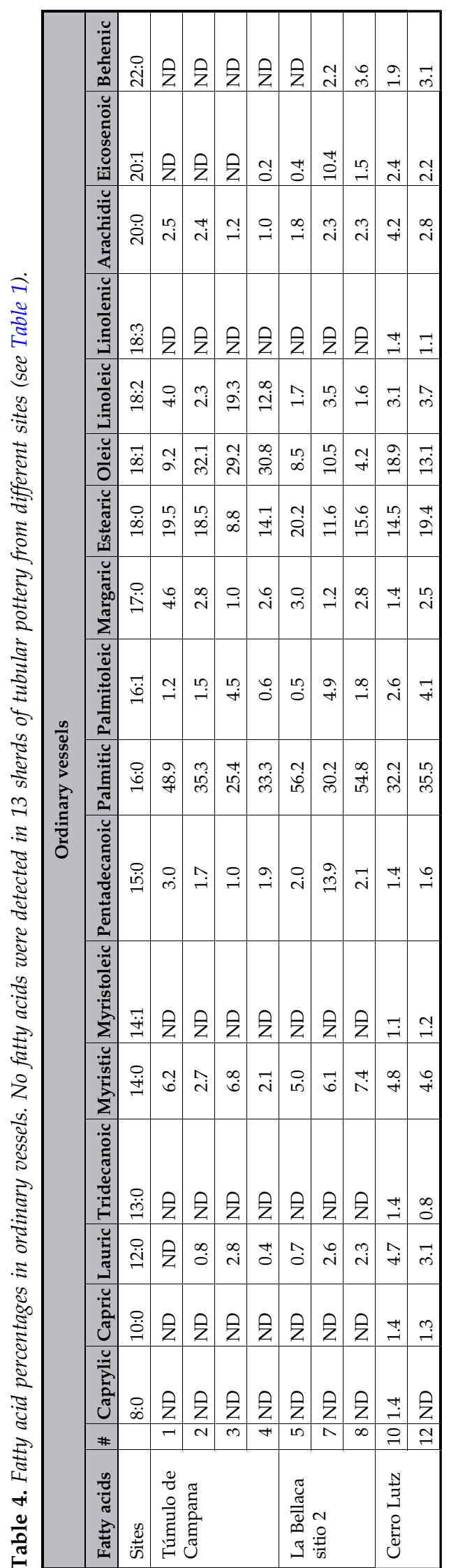

like a pestle. Most had black drawings on a white background ... they could not be penetrated because under the big pitchers there were two or three small pitchers of the same shape; also because some were closed and others not; and, finally, in every grave there was one of these pitchers with three holes, one in one side, another in the middle and another in the bottom. These holes allowed the spirit in his jar to feel the sun and the wind, and to record in comfort what was happening outside and inside the grave, when he wanted to live in retirement] (Sánchez Labrador 1910, 93-4, author's translation)

The second description we include here is by Félix de Azara, a naturalist living in the same region at the end of the eighteenth century, who referred to the same indigenous groups:

Hasta poco ha los enterraban sentados, dejándoles la cabeza fuera cubierta con una olla o campana de barro cocida ... arrancándole las yerbas y poniendo encima muchas campanas de barro boca abajo, y unas dentro de otras.

[Until recently they buried (their dead) in a sitting position, leaving the head above ground and covered with a pot or a bell made of fired mud ... tearing up the grass and putting many of these mud bells upside down, each one inside another.] (Azara [1847] 1943, 149 , author's translation)

These ethnographic descriptions practically describe tubular artifacts. In the first place, there is a remarkable morphological similarity, as the ethnographic pieces are bell-shaped with holes in the basal, apical and medial sectors. These are noticeable coincidences. In addition, there is an impressive concurrence related to the whitened surface, which is also an exceptional similarity to the tubular artifacts. Only the 'black drawings' were not recorded in the archaeological devices, which is a minor difference; however, black paint usually contains manganese compounds which could eventually have been lost. It is very interesting to note that none of the chroniclers indicated that these 'bells' were utilitarian objects, but that they seem to have been manufactured specifically for mortuary purposes, with a precise symbolic meaning. This would to a large extent explain the absence of organic residues. There are also no indications that they were associated with combustion structures, which would also explain the absence of carbon deposits and the presence of volatile manganese compounds in the archaeological pieces. The use of different sized 'bells' could also explain, at least in part, the dimensional variability in some contexts, where the smaller ones could 

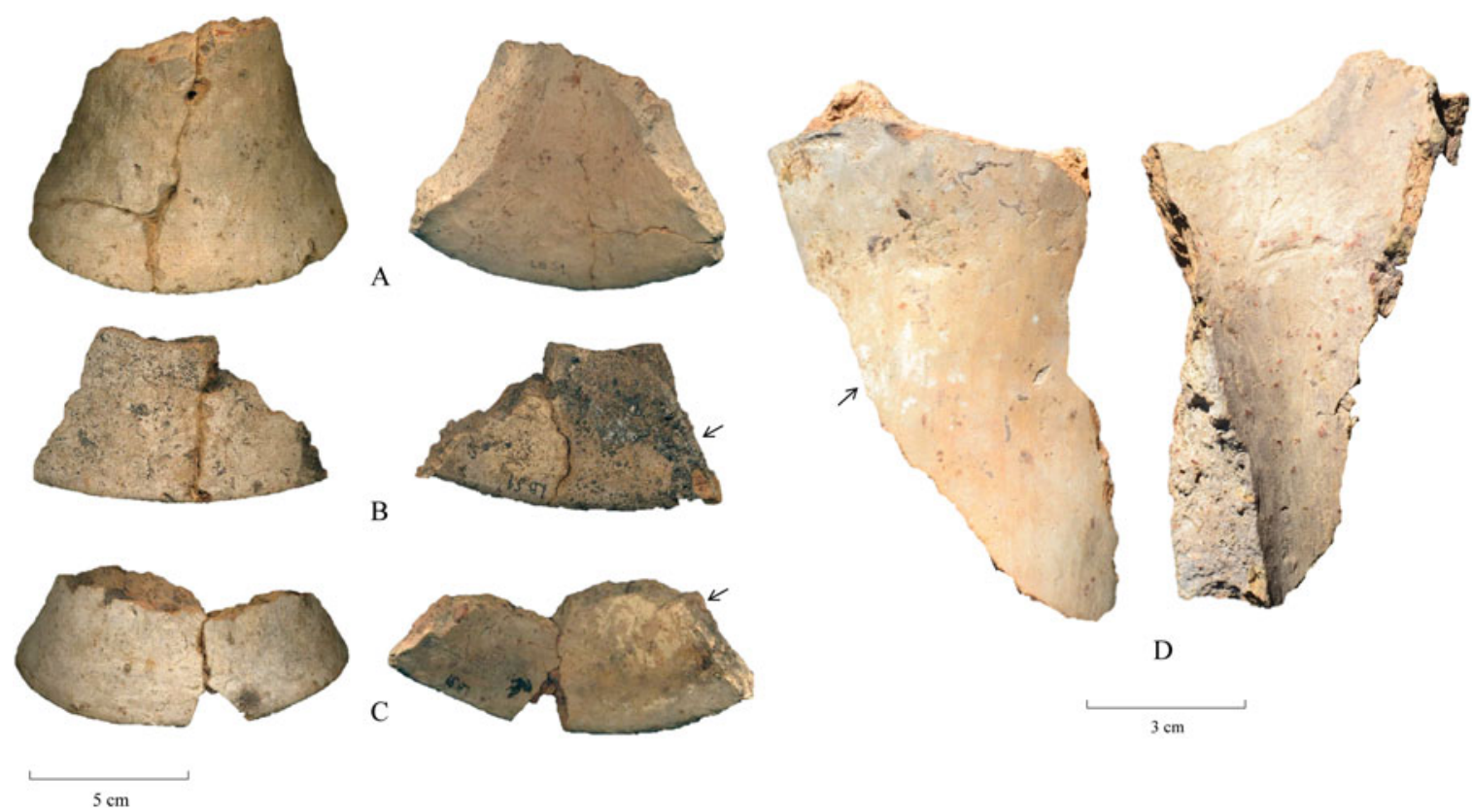

D

Figure 14. Sherds from tubular artifacts. Piece B with internal adherence (right). Piece $C$ with internal white paint (right). Piece D with external white paint.

have been put inside the larger ones, including miniatures. It should be noted that incised designs always decorate the apical end of these devices (i.e. Figs 2C, 4A \& 4B), as well as the zoomorphic appendages (when they had them), which is the sector where they should be seen. In the same way, the medial hole should be above the surface of the ground. Thus, if the tubular artifacts were partially buried in the subsurfaces of the tombs, the probability of their being displaced and not integrated into the grave pits is very high, which would explain why they are not regularly recovered in association with mortuary structures and the peculiar fracture process of these devices.

As a result of using tubular pottery in their tombs, these artifacts would have been signalling the surface, constituting one way of gaining ownership over the landscape. The stylistic information about these devices, especially those with incised and/or zoomorphic appendages, could also constitute a sign of the ethnicity, lineage and/or personal identity of the buried individual, as well as giving a powerful symbolic message, whereby people's spirits (following ethnographic descriptions) could be connected to the outside world.

\section{Conclusions}

The use of constructive techniques, morphologies and singular stylistic resources that were articulated for the elaboration of tubular artifacts is best explained by actions closely associated with symbolic aspects, as has been postulated for other contexts and artifacts (Gosselain \& Livingstone Smith 2005). The particular stylistic attributes, such as those evidently observed in tubular pieces, emit meanings intended to be observed both by the community and by other individuals, constituting a powerful means of symbolic communication (Wobst 1977; 1999). In this way, the peculiar sum of the attributes of these artifacts arranged on the surfaces of tombs would have had a visible symbolic message for those individuals who could decode it; as precisely the visibility and external appearance were a crucial aspect of the symbolic contents (cf. Wiessner 1983).

There are few examples in the world of pottery that were manufactured exclusively for mortuary purposes. Some classic examples include the canopic vessels from the dynastic period in Egypt (Budge 2010), the contexts of the Neolithic period in northwest China (Hung 2011; Underhill 2002) and some miniatures that would have been manufactured for mortuary rituals in some pre-Columbian Andean societies (Valdez et al. 2006). All of these cases refer to state or Neolithic/Formative societies. In our case, if tubular artifacts were mortuary pottery, and we believe that this is for now the best available hypothesis, they would be the first example in the world to be identified for complex hunter-gatherer societies. 
Daniel Loponte

CONICET

National Institute of Anthropology

3 de febrero 1378 (C1426BJN)

Buenos Aires

Argentina

E-mail:dashtown@gmail.com

Flavia Ottalagano

CONICET

National Institute of Anthropology

3 de febrero 1378 (C1426BJN)

Buenos Aires

Argentina

E-mail: flaviaott7@gmail.com

Maricel Pérez

CONICET

National Institute of Anthropology

3 de febrero 1378 (C1426BJN)

Buenos Aires

Argentina

E-mail:maricelperez@gmail.com

Laura Malec

Department of Organic Chemistry

Faculty of Exact and Natural Sciences

University of Buenos Aires

Int. Güiraldes s/n, (C1428)

Buenos Aires

Argentina

E-mail:malec@qo.fcen.uba.ar

Cinthia Ramos

Department of Experimental Physics of Condensed Matter

Institute of Nanoscience and Nanotechnology (INN)

National Atomic Energy Commission $\mathcal{E}$

CONICET

Av. Gral. Paz 1499 (C1650) Villa Maipú

Buenos Aires

Argentina

E-mail: ciramos@cnea.gov.ar

Patricia Bozzano

Materials Department

Constituyentes Atomic Center

National Atomic Energy Commission

Av. Gral. Paz 1499 (C1650) Villa Maipú

Buenos Aires

Argentina

E-mail: pbozzano@cnea.gov.ar
Manuel Iribarren

National Atomic Energy Commission $\mathcal{E}$ National University of General San Martin Av. Gral. Paz 1499 (C1650) Villa Maipú

Buenos Aires

Argentina

E-mail: manuel.iribarren@gmail.com

Rodolfo Pérez

National Atomic Energy Commissione

CONICET

Av. Gral. Paz 1499 (C1650) Villa Maipú

Buenos Aires

Argentina

E-mail:rodperez@cnea.gov.ar

Graciela Leiva

Department of Organic Chemistry

Faculty of Exact and Natural Sciences

University of Buenos Aires

Int. Güiraldes s/n, (C1428)

Buenos Aires

Argentina

E-mail: gleiva@gmail.com

Silvia Dominguez Materials Department

Constituyentes Atomic Center

National Atomic Energy Commission

Av. Gral. Paz 1499 (C1650) Villa Maipú

Buenos Aires Argentina

E-mail: sdoming@cnea.gov.ar

Sheila Alí

CONICET

National Institute of Anthropology 3 de febrero 1378 (C1426BJN)

Buenos Aires

Argentina

E-mail: sheilagriselali@gmail.com

Alejandro Acosta

CONICET

National Institute of Anthropology

3 de febrero 1378 (C1426BJN)

Buenos Aires

Argentina

E-mail: acostaalejandroalberto@gmail.com 


\section{References}

Aldazabal, V., 1995-96. Estilos cerámicos en la Costa Central de la provincia de Bs. As. [Ceramic styles on the Central Coast of the province of Buenos Aires]. Paleoetnológica 8, 95-107.

Aston, D.A., 1989. Ancient Egyptian 'fire dogs' - a new interpretation. Mitteilungen des Deutschen Archäologischen Instituts Abteilung Kairo 45, 27-32.

Aversente, Y., D. Loponte \& A. Acosta. Organic residues of pre-Columbian symbolic pottery of the Paraná River, South America. Ms.

Azara, F. de, [1847] 1943. Descripción e Historia del Paraguay y del Río de la Plata [Description and history of Paraguay and the Río de la Plata]. Buenos Aires: Bajel.

Barnard, H. \& J.W. Eerkens, 2007. Theory and Practice of Archaeological Residue Analysis. (BAR International series S1650.) Oxford: Archaeopress.

Brand, R.A., 1987. NORMOS programs. Internal report, Angewandte Physik, Universität Duisburg.

Brunazzo, G.A., 1999. Investigaciones arqueológicas en el sitio La Norma (Partido de Berisso, Provincia de Buenos Aires, Argentina) [Archaeological investigations at the La Norma site (Berisso county, province of Buenos Aires, Argentina]. Actas del XII Congreso Nacional de Arqueología Argentina 3, 101-6.

Budge, E.W., 2010. The Mummy: A handbook of Egyptian funerary archaeology. New York (NY): Cambridge University Press.

Caggiano, M.A., 1982. Análisis y desarrollo cultural prehispánico de la cuenca inferior del Plata [Analysis and prehispanic cultural development of the Lower Plata Basin]. Unpublished report. Buenos Aires, Consejo Nacional de Investigaciones Científicas y Técnicas.

Caggiano, M.A., 1984. Prehistoria del NE Argentino. Sus vinculaciones con la República Oriental del Uruguay y Sur de Brasil [Prehistory of the Argentine northeast. Its links with the Oriental Republic of Uruguay and southern Brazil]. Pesquisas Antropología 38, 5-109.

Charters, S., R.P. Evershed, L.J. Goad, P.W. Binkhorn \& V. Denham, 1993. Quantification and distribution of lipid in archaeological ceramics: implications for sampling potsherds for organic residue analysis and the classification of vessel use. Archaeometry 35, 211-23.

Christie, W.W., 1989. Gas Chromatography and Lipids. Dundee: Oily Press.

Condamin, F., M.O. Formenti, M. Michel \& P. Blond, 1976. The application of gas chromatography to the tracing of oil in ancient amphorae. Archaeometry 18, 195-201.

Craig, O.E., V.J. Steele, A. Fischer, et al., 2011. Ancient lipids reveal continuity in culinary practices across the transition to agriculture in Northern Europe. Proceedings of the National Academy of Sciences of the United States of America 108(44), 17910-15.
Deal, M. \& P. Silk, 1988. Absorption residues and vessel function. A case study from the Maine-Maritimes region, in A Pot for All Reasons. Ceramic ecology revisited, eds C.C. Kolb \& L.M. Lackey. Philadelphia (PA): Temple University, Laboratory of Anthropology, 105-25.

Díaz, A.A., 1977. Arqueología de Salto Grande. Secuencia cultural resultante de las investigaciones realizadas en Isla de Arriba y del Medio (Uruguay) [Archeology of Salto Grande. Cultural sequence resulting from research carried out in Isla de Arriba and del Medio (Uruguay)]. Actas del V Encuentro de Arqueología del Litoral, 154-74.

Eerkens, J.W., 2002. The preservation and identification of Piñon resins by GC-MS in pottery from the Western Great Basin. Archaeometry 44, 95-105.

Eerkens, J.W., 2005. GC-MS analysis and fatty acid ratios of archaeological potsherds from the Western Great Basin of North America. Archaeometry 47(1), 83 102.

Eerkens, J.W., 2007. Organic residue analysis and the decomposition of fatty acids in ancient potsherds, in Theory and Practice in Archaeological Residue Analysis, eds H. Barnard \& J.W. Eerkens. (BAR International series S1650.) Oxford: Archaeopress, 90-98.

Escudero, S. \& M. Coll, 2013. Sitios Bajada Guereño, Boca del Seco y Playa Mansa [The sites of Bajada Guereño, Boca del Seco and Playa Mansa], in Cerámica Prehispánica de Tierras Bajas de Argentina [Prehispanic pottery of the lowlands of Argentina], eds D. Loponte \& M. Pérez. Buenos Aires: Instituto Nacional de Antropología y Pensamiento Latinoamericano 1, 20-30.

Evershed, R.P., 1993. Biomolecular archaeology and lipids. World Archaeology 25, 74-93.

Evershed, R.P., C. Heron, S. Charters \& L.J. Goad, 1990. Chemical analysis of organic residues in ancient pottery: methodological guidelines and applications, in Organic Residues in Archaeology: Their identification and analysis, eds R. White \& H. Page. London: United Kingdom Institute for Conservation, Archaeology Section, 11-25.

Evershed, R.P., H.R. Mottram, S.N. Dudd, S. Charters, A. W. Stott \& G.J. Lawrence, 1997. New criteria for the identification of animal fats preserved in archaeological pottery. Naturwissenschaften 84, 402-6.

Farías, M., 2005. El Guaraní arqueológico meridional: Entre el axioma y la heterodoxia [The southern archaeological Guarani: between axiom and heterodoxy]. Ph.D dissertation, Pontificia Universidade Catolica de Rio Grande do Sul.

Freitas, C., 1942. Alfarería del Delta del Río Negro (Paradero 'La Blanqueada') [Pottery of the Río Negro River Delta (La Blanqueada site)]. Revista histórica 13(38-39), 363-418.

Freitas, C., 1953a. Alfarería del Delta del Río Negro (Paradero 'La Blanqueada') [Pottery of the Río Negro River Delta (La Blanqueada site)]. Revista Sociedad Amigos de la Arqueología 12, 65-119. 
Freitas, C., 1953b. Algunos aspectos de la Arqueología del Río Uruguay [Some aspects of the archaeology of the River Uruguay]. Revista Sociedad Amigos de la Arqueología 12, 147-83.

Frenguelli, J., 1927. Nuevo tipo de alfarería indígena ornitomorfa [A new type of indigenous ornithomorphic pottery]. Boletín de Educación de Santa Fe 4(24), 11-21.

Frère, M.M., 2015. Tecnología cerámica de los cazadores-recolectores-pescadores de la microrregión del río Salado, provincia de Buenos Aires [Ceramic technology of hunter-gatherers-fishermen from the microregion of the Salado River, province of Buenos Aires]. Ph.D dissertation, Universidad Nacional de Buenos Aires.

García Rosselló, J. \& M. Calvo Trias, 2013. Making Pots. El Modelado de la cerámica a mano y su potencial interpretativo. (BAR International series S2540.) Oxford: British Archaeological Reports.

Gaspary, F., 1945. Las campanas Chaná-Timbúes [The Chaná-Timbúes bells]. Revista Geográfica Americana XXIII, 140, 279-82.

Gaspary, F., 1950. Investigaciones Arqueológicas y Antropológicas en un Cerrito de la Isla Los Marinos (Pcia. de Entre Ríos) [Archaeological and anthropological investigations in a Cerrito of Los Marinos Island (Province of Entre Ríos)]. Publicaciones del Instituto de Arqueología, Lingüística y Folklore 23, 3-66.

Ghiani Echenique, N., A.R. Uvietta \& R. Gambaro, 2013. Alfarerías tubulares en el noreste de la provincia de Buenos Aires: caracterización y distribución [Tubular pottery in the northeast of the province of Buenos Aires: characterization and distribution]. Revista del Museo de La Plata. Sección Antropología 13 (87), 299-314.

González, M.I., 2005. Arqueología de alfareros, cazadores y pescadores pampeanos [Archaeology of potters, hunters and fishermen of the Pampas]. Doctoral thesis, Universidad Nacional de Buenos Aires.

Gosselain, O. \& A. Livingstone Smith, 2005. The source clay selection and processing practices in Sub-Sahara Africa, in Pottery Manufacturing Process: Reconstitution and interpretation, eds A. Livingstone Smith, D. Bosquet \& R. Martineau. (BAR International series S1349.) Oxford: Archaeopress, 33-47.

Heron, C., R.P. Evershed \& L.J. Goad, 1991. Effects of migration of soil lipids on organic residues associated with buried potsherds. Journal of Archaeological Science 18, 641-59.

Hilbert, K., 1991. Aspectos de la arqueología de Uruguay [Aspects of the archaeology of Uruguay]. Mainz am Rhein: Philipp von Zabern.

Hung, L., 2011. Pottery Production, Mortuary Practice, and Social Complexity in the Majiayao Culture, NW China (ca. 5300-4000 BP). PhD thesis, Washington University in St. Louis.

Indarti, E., M.I. Abdul Majid, R. Hashim \& A. Chong, 2005. Direct FAME synthesis for rapid total lipid analysis from fish oil and cod liver oil. Journal of Food Composition and Analysis 18, 161-70.

Johnson, J.S., J. Clark, S. Miller-Antonio, D. Robins, M. B. Schiffer \& J.M. Skibo, 1988. Effects of firing temperature on the fats of naturally occurring organic matter in clays. Journal of Archaeological Science 15, 403-14.

Lafon, C.R., 1971. Introducción a la Arqueología del Nordeste argentino [Introduction to the archaeology of the Argentine northeast]. Relaciones de la Sociedad Argentina de Antropología 2, 119-52.

Loponte, D.M., 2008. Arqueología del Humedal del Paraná Inferior (Bajíos ribereños meridionales) [Archaeology of the Lower Paraná Wetland (southern river banks)]. Buenos Aires: Asociación Amigos del Instituto Nacional de Antropología y Pensamiento Latinoamericano.

Loponte, D. \& A. Acosta, 2016. Los contextos Goya-Malabrigo del nordeste argentino [The Goya-Malabrigo contexts of northeastern Argentina]. Caderno do Ceom. Estudos regionais de arqueologia 29(45), 125-87.

Lothrop, S.K., 1932. Indians of the Paraná Delta River. Annals of the New York Academy of Sciences 33, 77-232.

Malainey, M.E., 2007. Fatty acid analysis of archaeological residues: procedures and possibilities, in Theory and Practice of Archaeological Residue Analysis, eds H. Barnard \& J. Eerkens. (BAR International series S1650.) Oxford: Archaeopress, 77-89.

Malainey, M.E., R. Przybylski \& B.L. Sherriff, 1999. Identifying the former contents of Late Precontact period pottery vessels from western Canada using gas chromatography. Journal of Archaeological Science 26, 425-38.

Márquez Miranda, F., 1932. Arqueología de la laguna de Lobos [Lobos lagoon archaeology], in Actas XXV Congreso Internacional Americanistas 2, 75-119. La Plata.

Métraux, A., 1937. Etudes d'ethnographies Toba-Pilaga (Gran Chaco). Anthropos 32(1-2), 171-94.

Métraux, A., 1944. Estudios de etnografía chaquense [Chaco ethnography studies]. Anales del Instituto de Etnografía Americana 5, 263-314.

Métraux, A., 1946. Ethnography of the Chaco, in Handbook of South American Indians, Vol. 1. The Marginal Tribes, ed. J. Steward. Washington (DC): Smithsonian Institution, 197-370.

Murad, E. \& U. Wagner, 1998. Clay and clay minerals: the clay firing process. Hyperfine Interactions 117, 337-56.

Oliveira Cézar, F. de, 1895. Datos arqueológicos. Proximidad de Buenos Aires. Boletín del Instituto Geográfico Argentino 16.

Ottalagano, F., 2013. Aves simbólicas, Estilo e Identidad en la Arqueología del Gran Río Sudamericano: Un estudio Contextual del Arte Cerámico de las Sociedades Prehispánicas de la Cuenca del Paraná Medio [Symbolic birds. Style and identity in the archaeology of the Great South American River: a contextual study of the ceramic art of the pre-Hispanic societies of the Middle Paraná Basin]. Buenos Aires: 
Instituto Nacional de Antropología y Pensamiento Latinoamericano.

Ottalagano, F., 2015. Explorando la variabilidad petrográfica entre vasijas decoradas y lisas del sitio La Palmera 2 (Entre Ríos, Argentina): hacia un abordaje microscópico del arte cerámico prehispánico de la cuenca del río Paraná [Exploring the petrographic variability between decorated and smooth vessels of the La Palmera 2 site (Entre Ríos, Argentina): towards a microscopic approach to the pre-Hispanic ceramic art of the Paraná river basin]. Revista Chilena de Antropología 32. DOI: 10.5354/0719-1472.2016.42498

Ottalagano, F. \& M. Pérez, 2013. Estudios petrográficos comparativos: un acercamiento regional a la tecnología cerámica del Delta del Paraná [Comparative petrographic studies: a regional approach to ceramic technology in the Paraná Delta]. Cuadernos del Instituto Nacional de Antropología y Pensamiento Latinoamericano, Series Especiales 1(2), 74-91.

Ottalagano, F., Domínguez, S. \& P. Bozzano, 2015. Arqueología de los colores: análisis MEB-EDX de mezclas pigmentarias en cerámicas prehispánicas de la cuenca del río Paraná (provincia de Entre Ríos, nordeste de Argentina) [Archaeology of colours: MEB-EDX analysis of pigment mixtures in pre-Hispanic ceramics of the Paraná river basin (province of Entre Ríos, Northeast Argentina)]. Boletín del Museo Chileno de Arte Precolombino 20(2), 57-68.

Ottalagano, F., M. Reinoso \& M. Freire, in press. Análisis químico de pinturas en alfarerías de estilo Goya-Malabrigo (nordeste de Argentina) [Chemical analysis of paints in Goya-Malabrigo pottery style (northeast Argentina)]. Boletín del Museo Chileno de Arte Precolombino 25(1).

Palavecino, E., 1933. Los indios Pilagá del río Pilcomayo [The Pilagá indians of the Pilcomayo River]. Anales del Museo Nacional de Buenos Aires 37, 517-82.

Palavecino, E., 1939. Las culturas aborígenes del Chaco [The aboriginal cultures of the Chaco], in Historia de la Nación Argentina, ed. R. Levene. Buenos Aires: El Ateneo-Academia Nacional de Historia, 387-417.

Paleo, M.C. \& M. Pérez Meroni, 2005-06. Dimensión social de la tecnología cerámica en sociedades cazadoras recolectoras [Social dimension of ceramic technology in hunter-gather societies]. Revista do Museu de Arqueología e Etnología 15-16, 73-85.

Paleo, M.C. \& M. Pérez Meroni, 2008. Relación forma-función en un conjunto alfarero del partido de Magdalena, Provincia de Buenos Aires: una aproximación metodológica [Form-function relationship in a pottery assemblage of the Magdalena county, Province of Buenos Aires: a methodological approach], in Problemáticas de la Arqueología Contemporánea [Problems of contemporary archaeology], eds. A. Austral \& M. Tamagnini. Río Cuarto: Universidad Nacional de Río Cuarto, 219-26.

Pérez, M., 2017. Tecnología de producción y uso de la alfarería durante el Holoceno tardio en el humedal del Paraná inferior [Technology of production and use of pottery during the Late Holocene in the Lower Paraná wetland]. PhD dissertation, Universidad Nacional de Buenos Aires.

Pérez, M., I. Acosta, G. Naranjo \& L. Malec, 2013. Uso de la alfarería y conductas alimenticias en el humedal del Paraná inferior a través del análisis de ácidos grasos [Use of pottery and feeding behaviours in the wetlands of the lower Paraná through the analysis of fatty acids]. Cuadernos del Instituto Nacional de Antropología y Pensamiento Latinoamericano Series Especiales 1(1), 26-45.

Rottländer, R., 1990. Lipid analysis in the identification of vessel contents, in Organic Contents of Ancient Vessels: Material analysis and archaeological investigation, eds W.R. Biers \& P.E. McGovern. (MASCA Research Papers in Science and Archaeology 7.) Philadelphia (PA): University Museum of Archaeology \& Anthropology, 37-40.

Rye, O.S., 1981. Pottery Technology. Principles and reconstruction. Washington (DC): Taraxacum.

Sackett, J., 1985. Style, ethnicity and stone tools, in Status, Structure and Stratification: Current archaeological reconstructions, eds R. Thomson, M. García \& F. Kense. Calgary: University of Calgary, 277-82.

Sánchez Labrador, J. 1910. El Paraguay católico [Catholic Paraguay]. Buenos Aires: Imprenta Coni.

Schmitz, P.I., C.N. Ceruti, A.R. González \& A. Rizzo, 1972. Investigaciones arqueológicas en la zona de Goya (Corrientes), Argentina [Archaeological investigations in the area of Goya (Corrientes), Argentina]. Dédalo 8(15), 11-121.

Serrano, A., 1922. Arqueología de las Tejas [Archaeology of Las Tejas]. Revista Universitaria del Litoral 12, 15-71.

Serrano, A., 1929. El área de dispersión de las llamadas alfarerías gruesas del territorio argentino [The dispersion area of so-called thick pottery in the Argentine territory]. Physis 10, 1-9.

Serrano, A., 1931. Arqueología del Litoral [Archaeology of the Littoral]. Arqueología. Memorias del Museo de Paraná 4, 1-5.

Serrano, A., 1933. Las Culturas Protohistóricas del Este Argentino y Uruguay [The protohistoric cultures of eastern Argentina and Uruguay]. Arqueología. Memorias del Museo del Paraná 7, 1-22.

Serrano, A., 1966. Manual de la cerámica indígena [Indigenous pottery manual ]. Córdoba: Editorial Assandri.

Serrano, A., 1972. Líneas fundamentales de la arqueología del Litoral (una tentativa de periodización) [Fundamental lines of the archaeology of the Littoral (an attempt at periodization)]. Publicación del Instituto de Antropología de la Universidad de Córdoba 32, 1-79.

Skibo, J.M., 2013. Understanding Pottery Function. New York (NY): Springer Science \& Business Media.

Skibo, J.M. \& M. Deal, 1995. Pottery function and organic residue: an appraisal, in Conference on Archaeology in South-East Asia, eds C. Yeung \& W.B. Li. Hong Kong: Hong Kong University Museum and Art Gallery, 321-30. 
Underhill, A.P., 2002. Craft Production and Social Change in Northern China. New York (NY): Kluwer Academic/ Plenum.

Torres, L.M., 1910. El Totemismo [Totemism]. Revista de la Universidad de Buenos Aires, serie 3 (13), 480-91.

Torres, L.M., 1911. Los Primitivos Habitantes del Delta del Paraná [The primitive inhabitants of the Paraná delta]. La Plata: Universidad Nacional de La Plata-Biblioteca Centenaria.

Valdez, L., J.S. Williams \& K. Bettcher, 2006. Wari mortuary practices at Marayniyoq, Ayacucho valley, Perú. Chungara, Revista de Antropología Chilena 38(1), 113-27.

Vignati, M.A., 1942. Alfarerías tubulares de la región de Punta Lara [Tubular pottery from the Punta Lara region]. Relaciones de la Sociedad Argentina de Antropología 3, 89-98.

Wagner, U., R. Gebhard, E. Murad, J. Riederer, I. Shimada, C. Ulbert \& F.E. Wagner, 1998. Science and archaeology. Philadelphia (PA): University of Pennsylvania Museum of Archaeology and Anthropology.

Wagner, U., R. Gebhard, W. Häusler, T. Hutzelmann, J. Riederer, I. Shimada, J. Sosa \& F.E. Wagner, 1999. Reducing firing of an early pottery making kiln at Batan Grande, Peru: a Mossbauer study. Hyperfine Interaction 122, 163-70.

Wagner, U., F E. Wagner, W. Hausler \& I. Shimada, 2000. The use of Mossbauer spectroscopy in Radiation in Art and Archeometry, eds D.C. Creagh \& D.A. Bradley. Amsterdam: Elsevier Science, 417-43.

Wiessner, P., 1983. Style and social information in Kalahari San projectile points. American Antiquity 48, 253-76.

Wobst, H.M., 1977. Stylistic behavior and information exchange, in Research Essays in Honor of James B. Griffin, ed. C.E. Cleland. (Anthropological Papers 61.) Ann Arbor (MI): University of Michigan, Museum of Anthropology, 317-42.

Wobst, H.M., 1999. Style in archaeology or archaeologists in style, in Material Meanings: Critical approaches to the interpretacion of material culture, ed. E.S. Chilton. Salt Lake City (UT), University of Utah Press, 118-32.

\section{Author biographies}

Daniel Loponte is a researcher at CONICET-INAPL. His research focuses on the archaeology of Eastern South America, material cultural, palaeoenvironmental studies and cultural evolution.

Flavia Ottalagano is a researcher at CONICET-INAPL. Her work focuses on the archeology of the Paraná River basin, including pottery analysis and symbolic studies as well as the application of archaeometric techniques for the study of hunter-gatherer groups.

Maricel Pérez is a postdoctoral researcher at CONICETINAPL. Her research focuses on the archaeology of the Paraná River basin, with a special emphasis on pottery analysis.
Laura Malec is currently a Researcher and Assistant Professor at the Department of organic chemistry, Faculty of Exact and Natural Sciences, University of Buenos Aires. Research interest includes lipid composition and lipid oxidation in food and in archaeological pottery.

Cinthia Ramos currently works at the Department of Experimental Physics of Condensed Matter and Institute of Nanoscience and Nanotechnology (INN), National Atomic Energy Commission and CONICET, researching in condensed matter physics, materials science, nuclear, environmental, biomedical, geological and archaeological materials.

Patricia Bozzano is a researcher at the Materials Department of Constituyentes Atomic Center, National Atomic Energy Commission. Her work focuses on electron microscopy characterization of condensed matter, materials science, nuclear, geological and archaeological materials.

Manuel Iribarren is a senior researcher at the National Atomic Energy Commission and a professor at the National University of General San Martin. His research areas include the diffusion, phase transformations, thermal treatments and elementary analysis of compositions in all kinds of materials.

Rodolfo Ariel Pérez is a researcher at the National Atomic Energy Commission and CONICET. He is also professor of the National University of General San Martin. His research areas include diffusion process in solids, techniques for chemical and physical detection and quantification of substances in all kind of materials.

Graciela Leiva is currently a researcher in the Department of Organic Chemistry, Faculty of Exact and Natural Sciences, University of Buenos Aires. Her research area is on science and food technology, including stability of dehydrated foods and analysis of food composition and food remains in archaeological materials.

Silvia Adriana Dominguez is a senior technician at the Materials Department of Constituyentes Atomic Center, National Atomic Energy Commission. Her work focuses on scanning electron microscopy characterization of materials science, nuclear, geological and archaeological materials.

Sheila $A l i$ is a doctoral researcher at CONICET-INAPL. Her research focuses on the archaeology of the Paraná River basin, with a special emphasis on pottery analysis and cultural evolution.

Alejandro Acosta is a researcher at CONICET-INAPL. His research focuses on the archaeology of Eastern South America, material cultural, paleoenvironmental studies and cultural evolution. 